\title{
Escaping the Middle-income Trap - A Cross-Country Analysis on the Patterns of Industrial Upgrading ${ }^{\mathrm{i}}$
}

\author{
Lili Wang ${ }^{1, *}$, Yi Wen ${ }^{2}$ \\ ${ }^{1}$ School of Economics and Management, Tsinghua University, Beijing China \\ ${ }^{2}$ Research Department, Federal Reserve Bank of St. Louis, USA
}

Copyright $\odot 2018$ by authors, all rights reserved. Authors agree that this article remains permanently open access under the terms of the Creative Commons Attribution License 4.0 International License

\begin{abstract}
With rapid industrial upgrading along the global value chain of manufactured goods, China has transformed, within one generation, from an impoverished agrarian society to a middle-income nation as well as the largest manufacturing powerhouse in the world. This article identifies the pattern of China's industrial upgrading and compares it with those of other successfully industrialized economies and the failed ones. We find that (i) China (since 1978) followed essentially the same path of industrial upgrading as that of Japan and the "Asian Tigers". These economies succeeded in catching up with the developed western world by going through three developmental stages sequentially; namely, a proto-industrialization in the rural areas, a first industrial revolution featuring mass production of labor-intensive light consumer goods, and then a second industrial revolution featuring mass production of the means of mass production (i.e., capital-intensive heavy industrial goods such as steel, machine tools, electronics, automobiles, communication and transport infrastructures). (ii) In contrast, economies stuck in the low-income trap or middle-income trap did not follow the above sequential stages of industrialization. For example, many Eastern European and Latin American countries after WWII jumped to the stage of heavy industrialization without fully developing their labor-intensive light industries, and thus stagnated in the middle-income trap. Also, there is a clear lack of proto-industrialization in the rural areas for many African economies that have remained in the low-income trap. We believe that laissez-faire and "free market" alone is unable to trigger industrial upgrading. Instead, correct government-led bottom-up industrial policies are the key to escaping the low- and middle-income traps.
\end{abstract}

Keywords China's Economic Development, Industrial Revolution, Middle-Income Trap, New Institutional Theory, New Stage Theory, New Structural Economics

JEL Codes: D30, E00, F02, F60, N10, O11, O40

\section{Introduction}

In less than 40 years, China has transformed from an impoverished agricultural country (with income per capita less than $\$ 250$ in the 1970s) to the world's largest manufacturing powerhouse (with income per capita around $\$ 8000$ in 2016). According to the standard of the World Bank, China successfully joined the ranks of middle-income countries.

But, starting in 2011 (a couple of years after the global financial crisis), China's income growth rate has slowed substantially, from a two-digit to a single-digit growth rate. The question is: Can China overcome the so-called "middle-income trap"?

The concept of "middle-income trap" first appeared in a research report by the World Bank. It refers to the phenomenon of some developing countries (or regions) losing momentum of growth after reaching a middle-income level (Gill \& Kharas, 2007[15]). Although this concept has since been used widely in the literature to describe stagnated growth in both absolute terms and relative terms regarding an economy's growth performance, we follow Arias and Wen (2015) [3] and define explicitly in this article an "income trap" as the phenomenon of an economy's aggregate income per capital failing to grow faster than the US (a representative of the developed world). As a result, this economy's income per capital relative to the US remains constantly and substantially below $50 \%$ (say, around $15 \%$ to $50 \%$ ), or even significantly below $10 \%$ (say, around $1 \%-5 \%$ ). The former situation is called a (relative) middle-income trap and the latter a (relative) low-income trap (or poverty trap).

As shown in Fig. 1 (top panel), Latin American countries such as Brazil, Columbia and Peru, and Eastern European countries such as Romania and Turkey, experienced essentially zero growth relative to the US economy, thus stuck in the middle-income trap, with per capita GDP hovering around $10 \%$ to $40 \%$ of the US level in the past 60 years. In sharp contrast, the "Asian tigers" such as Hong Kong, South Korea and Taiwan, achieved sustained growth 
faster than the US since the 1960s, striding across both the low- and the middle-income traps sequentially and joining the ranks of high-income countries recently.

Meanwhile, Fig. 1 (the bottom panel) also shows that Ethiopia, Niger, Malawi and other Sub-Saharan African countries have fallen into a low-income trap for a long time, with GDP per capita remaining below 5\% of the US level. In sharp contrast, China started to escape from the low-income trap by growing significantly faster than the US since late 1970s, and is now a middle-income country. India and Vietnam also show signs of escaping the low-income trap.

Obviously, the key to escaping or avoiding income traps is to maintain economic growth at a faster rate than the developed world. As noted by Arias and Wen (2015) [3], many poor countries have a per capita income only one-thirties or one-fifties of the US level (or even lower, with less than $\$ 1000$ per year), so for such countries to catch up with the US living standard, it may take at least 170 to 200 years - even assuming they can maintain a growth rate that is constantly 2 percentage points above the U.S. rate (which is about 3 percent per year), or maintaining a growth rate of 5 percent per year for 170 to 200 years, or even longer. This is really hard, if not impossible. It is even harder to imagine that such countries can reach the US living standard within one to two generations (e.g., 40 to 60 years). To achieve that, they need to grow 8 percentage points faster than the US (or 11 percent per year) non-stop for 40 to 60 years. In recent history, only China has been able to maintain a 10 percent annual growth rate (or 7 percentage points above the US rate) for 35 years. Hence, the lack of income convergence and relative income traps appears to be a real problem.

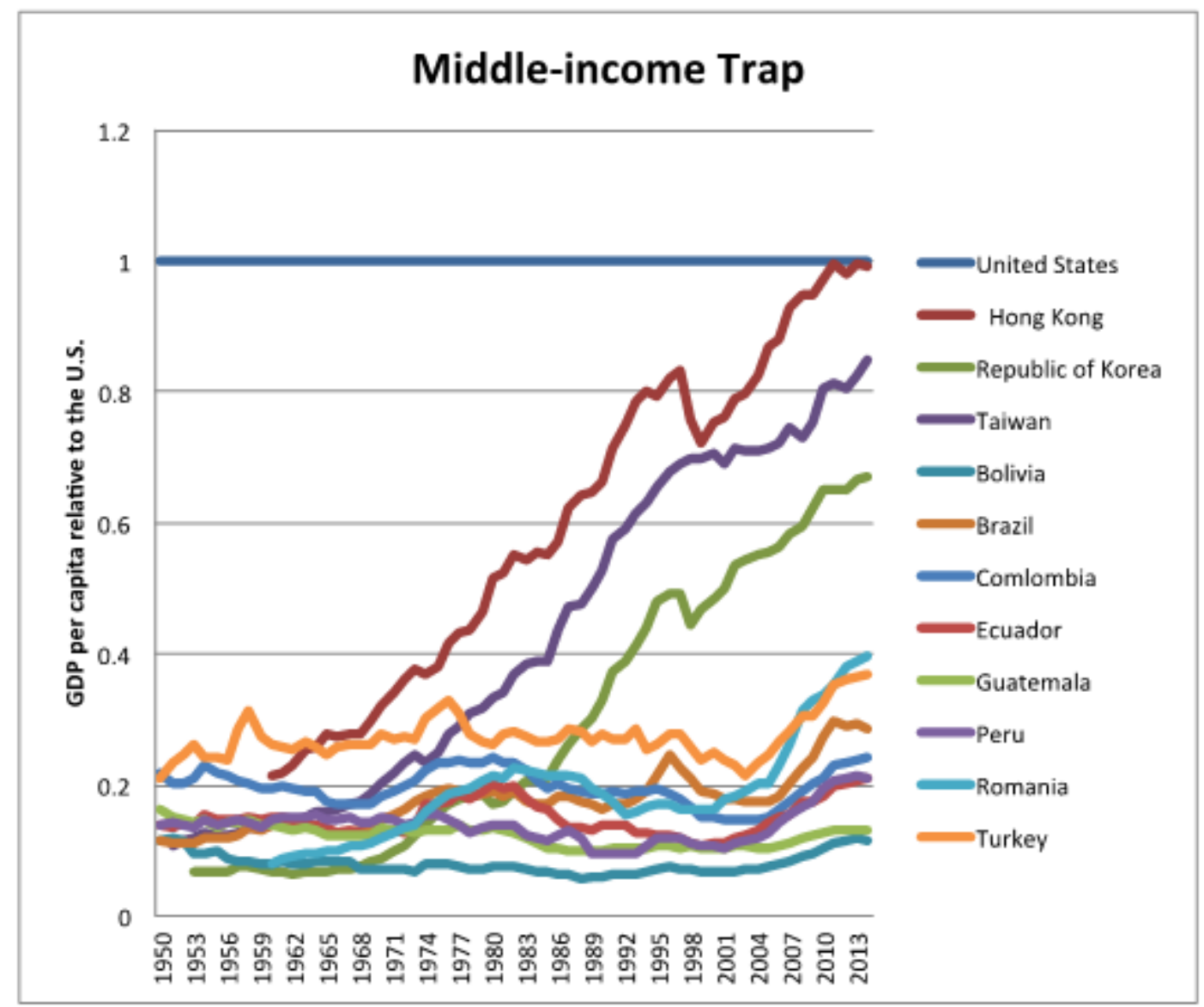




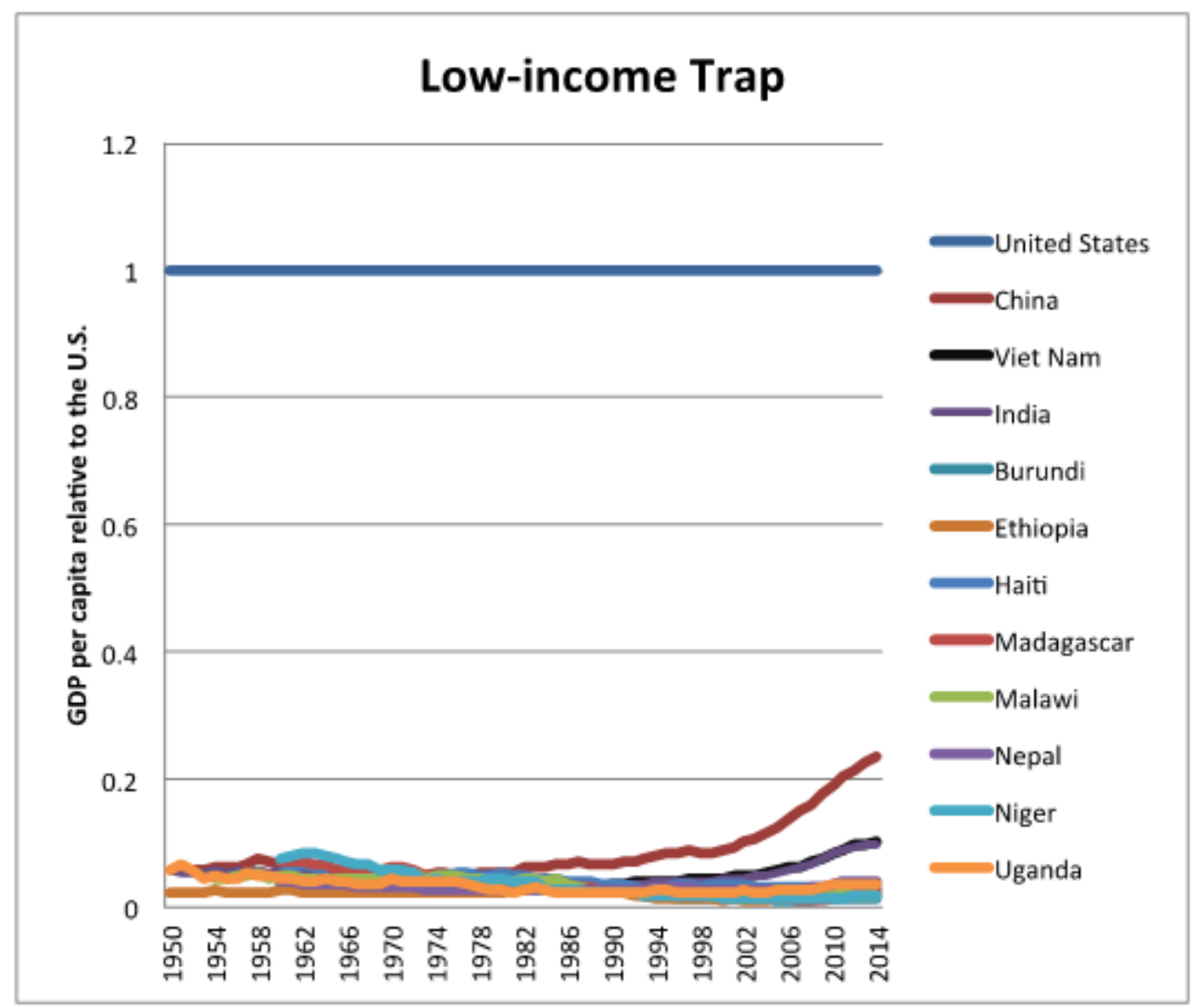

Data source: PWT90 and Authors' Calculation

Figure 1. Low-income and Middle-income Traps

But, what factors determine a country's long-term economic growth? This question has challenged generations of economists ever since Adam Smith. At the present, a popular mainstream theory holds that institutions and the rule of law are the prerequisites for economic growth. According to this view, the reason behind the economic stagnation in many countries is that private property right is not well protected because of "extractive" political institutions; thus, people are not motivated to engage in wealth accumulation and innovation (North, 1991[32]). To guarantee inclusive political institutions that can protect private property right and enforce the rule of law, they need democracy or universal suffrage (Acemoglu et al., 2001[1]).

However, such "new institutional theories" are difficult to square with the facts. First, there are ample democracies with pervasive economic stagnation and continuous political turmoil: Afghanistan, Egypt, Iraq, Libya, Pakistan, Thailand, Tunisia and Ukraine, to name a few. Second, there are ample countries with "extractive" institutions that have been economically strong, such as Germany (1850-WWII) and Soviet Russia (1860-WWII). The new institutional theory also cannot explain the dismal failure of today's Russia at economic reform under democracy and shock therapy, Japan's rapid industrialization during the Meiji Restoration, South Korea's economic takeoff in the 1960s-1980s under dictatorship or Singapore's post-independence economic miracle under the authoritarian government of Lee Kuan Yew. Nor can the theory explain that under identical political institutions, property rights, and the rule of law, there exist pockets of both extreme poverty and extreme wealth, as well as of violent crime and obedience to law. Such dichotomies exist in many US cities, for example. Italy is another example, with its poverty in the south and wealth in the north.

The new institutional theory also cannot explain China's miracle growth, because it has been achieved under an authoritarian government with enormous government interventions. In contrast, countries in Africa, Latin America and Eastern Europe are far more democratized, marketized, privatized, liberalized and deregulated than China, yet unable to grow like China, still troubled by sluggish growth and caught by low- or middle-income traps after so many years subscribing to the Washington Consensus. This contrast, however, by no means implies that market forces are not important or critical for China's achievement (since China was also caught in a poverty trap before its market-oriented reform in 1978), but it simply implies that market forces alone are far from sufficient, 
albeit necessary.

This is why the former World Bank chief economist Justin Lin $(2011,2013)[25,26]$ disagrees with the recipes of new institutional theories and Washington Consensus. $\mathrm{He}$ instead argues that in any market economies, correct industrial policies pushed by a facilitating government hold the key for economic development. In particular, all economies need industrial policies to succeed, but sound industrial policies must conform to an economy's endowment structure, so as to render domestic firms competitive in international markets. Sustainable economic development is driven by industrial policies that tackle a nation's comparative advantage and target industries consistent with its endowment structure, such as the labor-intensive industries in the early stage of industrialization. Hence, leap-frog development strategies that focus on heavy industries from the very beginning will fail because they defy an economy's comparative advantages and render firms non-viable and non-competitive in the international market.

Complementing to Lin's view, Wen (2016)[43] argues that targeting industries with comparative advantages is not enough. The state also needs to help create markets for firms according to comparative advantages. The fundamental reason is that the market is itself a public good, which individuals have few incentives and resources to create. Wen (2016)[43] points out that the "free market" has 3 pillars: political stability, social trust, and infrastructure, all of which determine the shape and extent of the market but are extremely costly to provide. Thus the market, especially unified mass market, can only be created by a strong mercantilist state. Such a state is willing to promote manufacturing through trade and is capable of market creation. According to Wen (2016)[43], this is the secret recipe of the British Industrial Revolution and the rise of Europe since the Great Voyage. China's rapid industrialization since 1978 can thus be attributed precisely to its rediscovery of this secret recipe. Unlike the new institutional theory and Washington consensus, this recipe is not based on institutional changes per se (which are largely endogenous), but rather on the sequential creation of mass markets to support mass production, following the endogenous evolution of an economy's endowment structure and comparative advantages. That is, economic development cannot be achieved by simply adopting a market system, as advocated by the laissez-faire philosophy, instead, how to adopt a market system, or the way market forces are introduced into the economy, matters. In other words, upon adopting market-oriented reforms, what is critical for growth is that the state needs to identify the correct sequence to create markets for domestic firms. Incorrect market-reform policies can lead to disasters, such as that experienced by Russia and other Eastern European countries under the shock therapy. This is exactly why the Washington Consensus failed. The fundamental reason behind this is that the so-called market is itself a public good, which has internal stability properties and structures and thus needs to be created sequentially overtime by the state.

More specifically, Wen (2016) [43] provides a conceptual framework, called the New Stage Theory (NST) of economic development (or the Embryonic Development Theory), to illuminate the correct sequence to introduce market forces by the state, which he calls "the central historical developmental logic" shared by both the Industrial Revolution and China's miraculous growth. The NST characterizes economic development as a process of sequential market creation and structural transformation, from an agrarian market structure to a proto-industrial market structure, then to a light-industrial market structure and subsequently to a heavy-industrial market structure, and finally, to a service-oriented welfare-state market structure. Each earlier developmental stage provides the necessary (but not sufficient) developmental conditions for entering the next stage, through successful (and successive) market creation led by the state. Failure to go through the necessary developmental stages sequentially with the right industrial policies will result in developmental failures, disorders, or immature industrialization and even deindustrialization, such as the relative "poverty trap" and the "middle-income trap" symptoms, regardless of political systems (e.g., Monarchy or Republic). Market-facilitating institutions are endogenous to economic development.

In other words, the NST emphasizes that for backward agrarian nations to catch up with developed nations, repetition of the earlier developmental stages of the British Industrial Revolution in human history is necessary and the only way to achieve successful industrialization, as China's miraculous growth has demonstrated once again after the success of the Asian tigers, Japan, West Europe, and North America. The NST advocates the Smithian principle that the division of labor is limited by the extent of the market. But the "free market" is not free and must be created through collective social forces (such as 16th-19th century state-led colonialism). It is the nature of geopolitics, social spirits, and infrastructure that determine the shape, depth, and extent of the free market, which in turn determines the degree of the division of labor and speed of industrialization. Therefore, the NST identifies missing market-creators as the key problem of development. In this paper, we quantitatively identify an empirical pattern of industrial upgrading across countries that sheds light on the sequential stages of economic development. This pattern of economic development is consistent with the development theories outlined in the New Structural Economics proposed by Justin Lin $(2011,2013)[25,26]$ and the New Stage Theory proposed by Wen (2016)[43].

The rest of the paper is structured as follows. Section 2 identifies the pattern of China's industrial upgrading after 1978 and compares it with the previous era of social planning between 1950 and 1978. Section 3 looks at the 
pattern of the successfully industrialized economies, such as Japan and the "Asian tigers." Section 4 looks at the pattern of industrialization for countries stuck in the low-income and middle-income traps. Section 5 concludes the paper with remarks for future research.

\section{China's Pattern of Industrialization}

\subsection{Failure in the Planning Era}

After the founding of the People's Republic of China, China started its industrialization by pursuing the heavy-industry oriented development strategy of the Soviet Union. Since the First Five-Year Plan, China established many industrial centers in big cities to produce heavy industrial goods such as automobiles, steel, and machine tools, with the help of the Soviet Union. During the Great Leap Forward, the whole nation was engaged in producing iron and steel. Steel production reached 11.08 million tons in 1958, more than doubling the level in 1957. However, over 3 million tons of steel and 4.2 million tons of iron were useless because of poor quality, which caused an estimated loss of nearly 20 billion yuan in that year (accounting for over $15 \%$ of GDP in that year). ${ }^{1} \mathrm{~A}$ continuation of the heavy-industry oriented developmental policy during the Cultural Revolution led to a continued rising proportion of heavy industries in total industrial output. As illustrated in Fig. 2, during the whole planning era, the ratio of light industries to heavy industries declined continuously and rapidly. For example, from 1952 to 1978, the ratio of value added between light industries and heavy industries declined from 1.4 to 0.6 , the ratio of employment between light and heavy industries declined from 2.5 to 0.5 , and the ratio of capital stock between light and heavy industries declined from 0.45 to $0.15 .^{2}$
Does it make economic sense to kick-start a full-fledged industrialization process in countries like China (with more than $90 \%$ of the population living in the rural areas) by prioritizing the capital-intensive heavy industries (other than essential defense industries and basic infrastructure projects)? It does not. First of all, China's industrialization started from scratch in the 1950s. Its domestic and international demand for heavy industrial goods, such as iron and steel, machine and automobiles was quite limited, given the penniless grassroots population $(90 \%$ of them were farmers) and hostile international environment. As a result, not only were the intermediate goods and parts not mass produced domestically, but the factories' output levels were often less than $30 \%$ to $50 \%$ of their potential production capacities. However, the market size must be at least $70 \%$ to $80 \%$ of the potential mass-production capacity in order to make such heavy industries profitable (Wen, 2016[43]).

Second, prioritizing iron and steel, machinery, automobiles and other capital-intensive industries defied China's endowment structure and comparative advantage (Lin, 2011[25]). When 90\% of the population lived in poor rural areas, the cheapest factor of production should be labor instead of capital. Thus, output produced using capital-intensive technologies at that time must be too expensive to be competitive in the international market, making such industries unprofitable and non-viable. As a result, to support heavy industries, the Chinese government must subsidize them heavily via severe price distortions and allocate enormous amount of scarce resources to unviable heavy-industrial firms, causing hardships in agriculture and light-industrial sectors and leading to a typical "shortage economy."

Interestingly, such an urban-oriented heavy-industry-based approach to industrialization was taken not only by communist China, but also by many market economies, such as India and other newly independent nations, as well as nearly all Latin American countries after World War Two (WWII). As will be shown shortly, all such economies have had trouble escaping the low- or middle-income traps. 

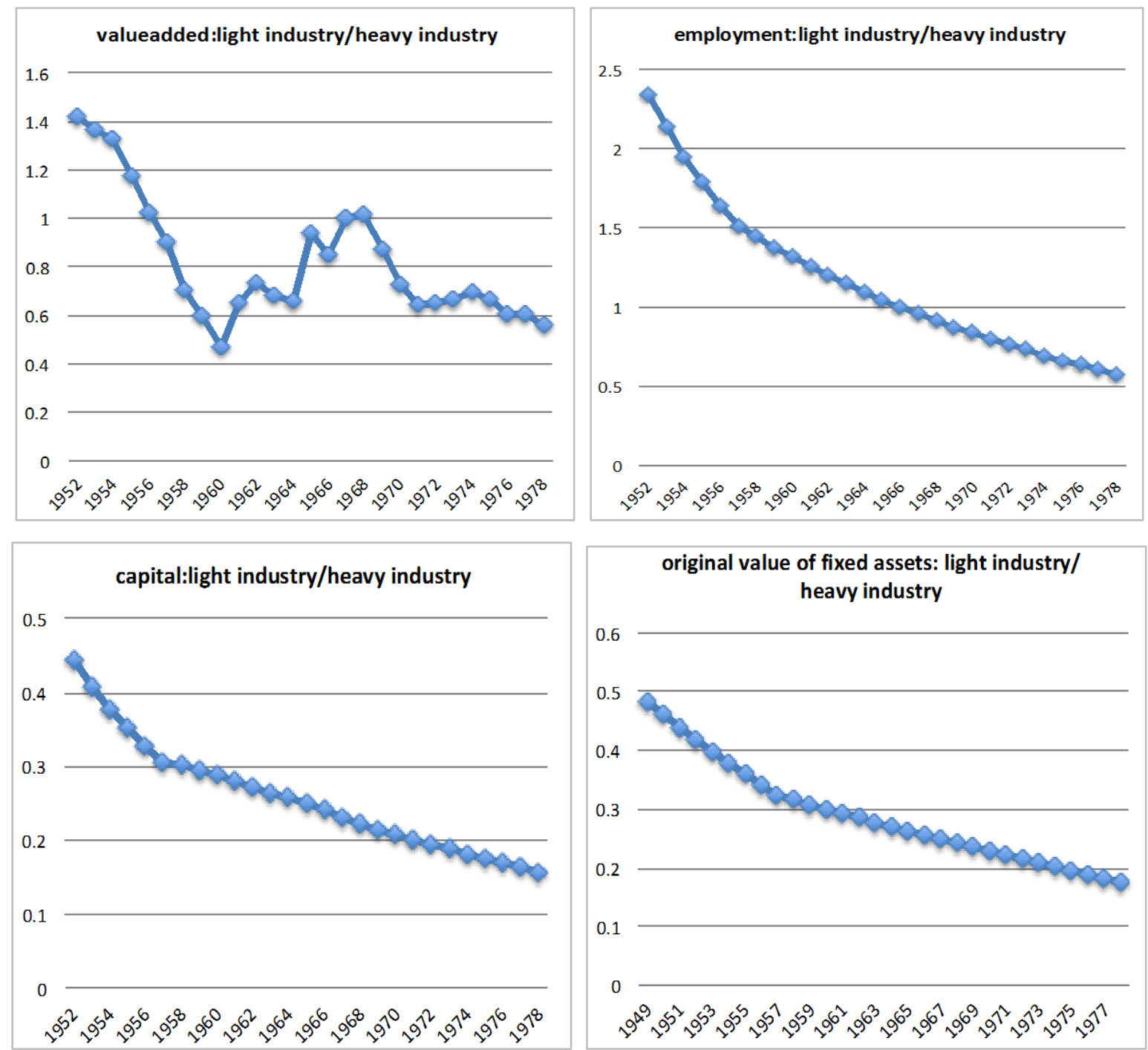

Data source: China Industrial Economy Yearbook and Authors' Calculation

Figure 2. China's Premature Heavy Industrialization before Reform

\subsection{China's Pattern of Industrial Upgrading after Reform}

\subsubsection{Rural Proto-Industrialization (1978-1988)}

After the 1978 reform, commerce was promoted and the state allowed natural resources to flow more freely to handicraft manufacturing and backyard industries, especially in the rural areas. As a result, township and village enterprises (TVEs) flourished in China - because farmers liked to find new ways to make money and local governments were required to develop local economies through more pragmatic means without fundamental changes in China's basic political institutions (which provided the needed political stability and social trust). Such political stability and social trust across China's vast territories connected by roads built during the planning era also meant a vastly unified domestic market for rural factories to sell their products in remote areas. With China's collective ownership of rural land remained intact, village and township governments were able to promote the setup of collectively owned TVEs by pooling land, farmers' savings, and rural surplus labor, significantly reducing the fixed costs of firm entry.

Within the initial ten years of prudent and pragmatic reform from 1978 to 1988 , gross output of rural industries increased by more than 13.5 -fold, from 51.5 billion yuan to 702 billion yuan; employment of rural industries increased by over 3-fold, from 28 million to 95 million; farmers' total income increased by 12 -fold, from 8.7 billion yuan to 96.3 billion yuan; and total capital of TVEs increased by over 9-fold, from 23 billion yuan to 210 billion yuan. ${ }^{3}$

TVEs continued to grow at an explosive speed in the 1990s. In 1992, non-agricultural activities in the rural areas had absorbed 103 million people, accounting for $24.2 \%$ of

3 Data source: Appendix Table 1 in "A Short History of China's Village Enterprises", by Zhang Yi and Zhang

Song-song, 2001, Chinese Agricultural Publication. 
total rural workforce. Among them, rural industries alone absorbed $61.4 \%$ of the non-agricultural labor force, and at that time only $12 \%$ of rural surplus labor was absorbed by urban areas. ${ }^{4}$ In 2000, the employment of TVEs reached more than 128 million (not including the migrant workers in the cities), accounting for a remarkable $30 \%$ of China's total rural workforce. Gross output of rural industries reached 11.6 trillion, a 16.5-fold increase compared with its 1988 value, or a 225 -fold increase compared with its 1978 value.

As illustrated in Fig. 3, the gross-output share of rural industries in total industrial production increased rapidly between 1978 and 1988, and the momentum was also kept in the following decade until the end of the 1990s. Thus, from 1978 to 2000, the gross-output share of rural industries in China increased from $10 \%$ to nearly $60 \%$.

TVEs tend to specialize in labor-intensive small-scale production of commodities such as processed food, textiles, garments, and footwear. Taking rural textile industry for example, from 1985 to 1989 , on average the number of rural textile firms increased by 1741 per year and the number of employees increased by 330.6 thousand per year, and gross output (in 1980 constant price) increased at an annual rate of $31.98 \%$, the value of fixed assets grew at an annual rate of $40 \%$, and sales revenue increased at an annual rate of $29.25 \%$. As another example, throughout the 1980 s, gross output of village and township textile industry in Jiangsu province grew at an average rate of $29.25 \%$ annually, gross output of cotton yarn rose by 7.84 times in 10 years, cotton cloth rose by 3.22 times, knitwear rose by 5.23 times, and silk fabrics rose by 10.35 times. $^{5}$

Wen (2016) [43] points out that rural-based proto-industrialization is an indispensable and necessary first step for agrarian economies to embark on an industrial revolution featuring mass production, because "mass production requires mass market and mass distribution to render it profitable," (Wen, 2016[43]). Yet a mass market relies on the purchasing power of grassroots population, which in turn relies on drawing massive amount of the grassroots population into manufacturing without jeopardizing food security. Hence, utilizing rural surplus labor to produce primitive labor-intensive products locally, not only can raise farmers' income and purchasing power, thus fermenting the market through long-distance trade, but also nurture entrepreneurship and labor skills, and improve distribution networks and commercial infrastructure. Such a proto-industrialization stage will eventually kick-start a nation-wide adoption of factory systems with

4 Data source:" China's Ternary Economic Structure and Transfer of Rural Surplus Labor", by Chen jiyuan and Hubiliang, 1994, Economic Research Journal, in Chinese

5 Data source: "Development of Village and Township Textile Industries in Jingsu, Zhejiang and Shandong," Joint investigation of department of policies and regulations, ministry of textile industry, and department of TVEs, ministry of agriculture, 1991, China Industrial Economic Research. labor-intensive mass-production technologies - the very feature of the First Industrial Revolution that took place in the United Kingdom 250 years ago after more than 200 hundred years of rural industrialization since 1550 (see Wen, 2016 [43] and Mendels, 1972[31]).

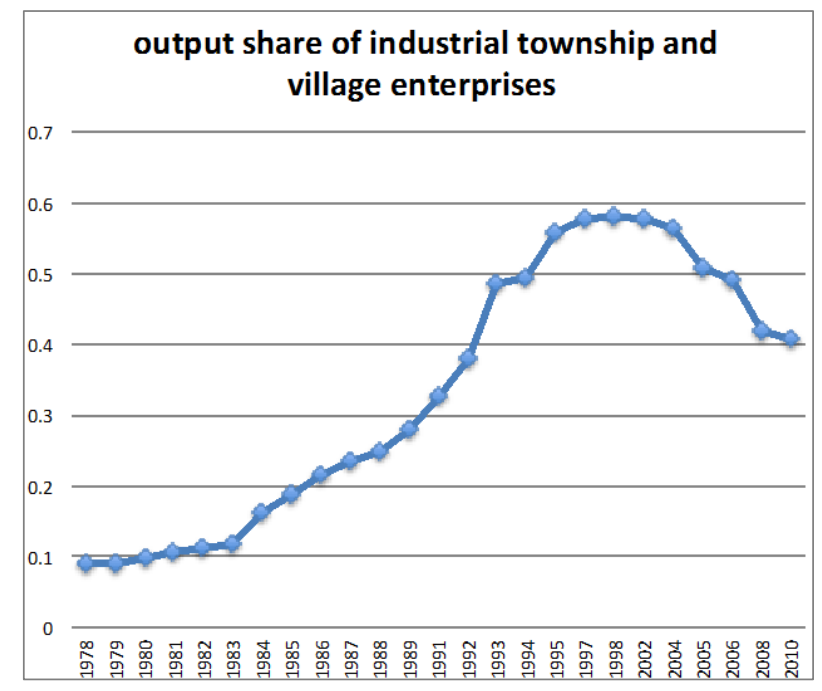

Data source: China Industrial Economy Yearbook, and China Yearbook of TVEs

Figure 3. China's Rural Industries after Reform

2.2.2. First Industrial Revolution: Mass Production of Labor-Intensive Light Industrial Goods (1988-1998)

With China's immense and explosive growth of TVEs and related commerce in the first decade after reform, the enormously expanded domestic market, improved supply chains, and the intensified competition among firms all make the adoption of mass production technologies and large-scale factory system profitable and necessary. So, starting in the late 1980s, the first industrial revolution similar to that in late 18th to early $19^{\text {th }}$ century England was kick-started in China, but with a speed 5-10 times faster. As happened in late $18^{\text {th }}$ century to early $19^{\text {th }}$ century England, the first industrial revolution features large-scale factory system with labor-intensive mass production of light consumer goods, which requires relatively low capital and energy, and is thus easier to finance with the accumulated domestic savings from rural proto-industrialization.

In the next ten years from 1988 to 1998, light industries such as textile, clothing, processed food and furniture etc. entered an explosive growth period that was large-scaled and thus even more dramatic than the first decade between 1978 and 1988. For instance, over the decade value added of light industries increased by nearly 5-fold, from 24.13 billion yuan in 1988 to 117.53 billion yuan in $1998 .{ }^{6}$

The first two decades after China's reform were a golden

6 Data source: China Industrial Economy Yearbook. Value added of light and heavy industries are not available before 1992, we use net output instead. Value added (or net output) is in current price. 
age for light industries. Data from China Industrial Economy Yearbook shows that the ratios of light industries to heavy industries in value added, labor input, capital and original value of fixed assets all increased rapidly during this period, reversing their sharp-declining trends in the previous planning era before the reform (Fig. 3). This rising trend did not stop until China finished its first industrial revolution around the late 1990s, by which time China reentered the phase of heavy industrialization, as illustrated by the hump-shaped pattern in Fig. 3 and in Fig. 4.

However, this new round of a heavy industrial boom since the late 1990s, unlike the previous one in the
$1950 \mathrm{~s}-70 \mathrm{~s}$, became sustainable and profitable, thanks to the tremendously enlarged market during the rural industrialization and the first industrial revolution periods and the enormously increased domestic savings from these periods. As a result, unlike East European countries after their market reform, China did not need to borrow heavily from international organizations such as the World Bank and the IMF to finance its heavy industrialization. It also no longer needed to heavily tax its farmers and distort domestic price systems to finance a heavy industrialization: Its colossal domestic savings were far from sufficient. You do things well only when you do them right.
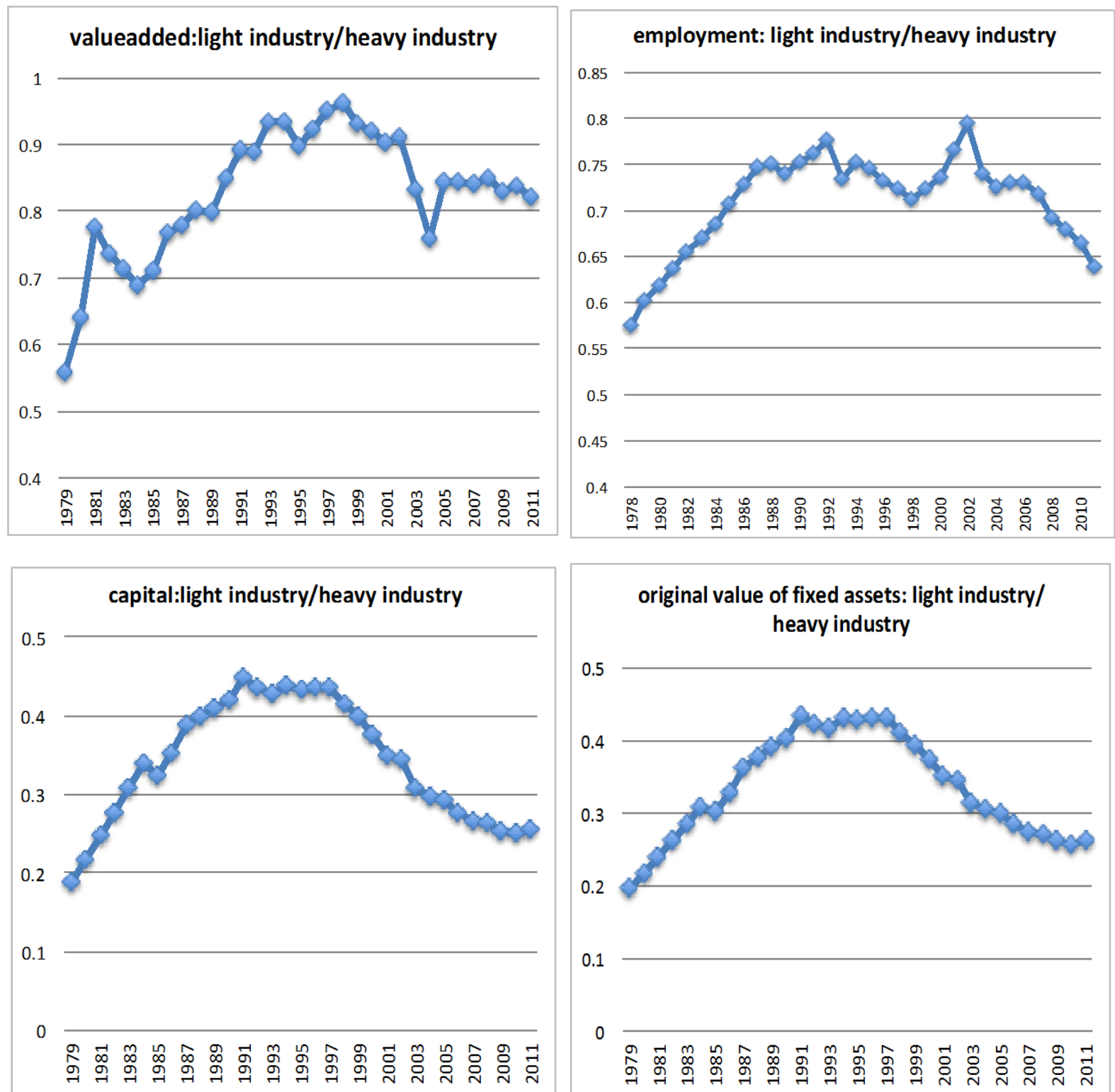

original value of fixed assets: light industry/ heavy industry

0.5

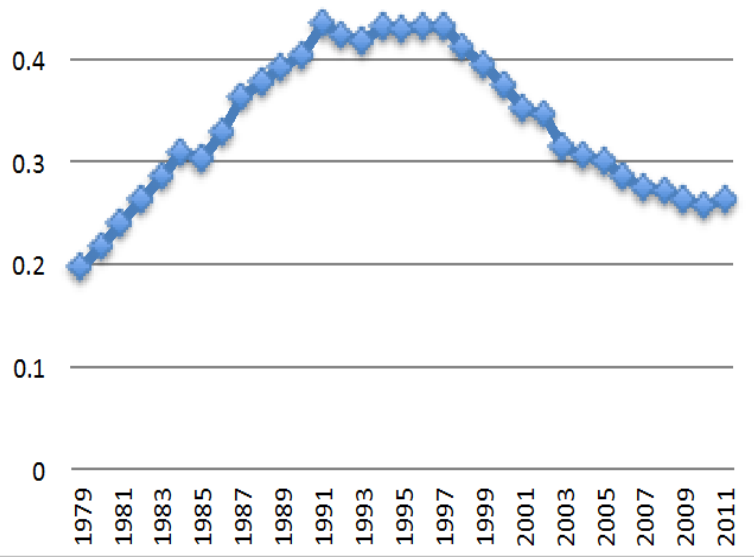

Data source: China Industrial Economy Yearbook and Authors' Calculation

Figure 4. China's Hump-shaped Ratios of Light Industries to Heavy Industries after Reform

Data show that from 1978 to 1998, light industrial value added increased by 14 -fold, at an annual growth rate of
$14 \%$. Even after price adjustment, annual real growth rate was still as high as $11 \%$. The number of workers in light 
industries rose by 2.2 times, from 18.28 million in 1978 to 40.17 million in 1998. In particular, by 1997, value added of textile industry reached 111.7 billion yuan, 7.5-fold of its value in 1978. Between 1978 and 1998, output of yarn rose from 2.32 million tons to 5.42 million tons, and output of cloth rose from 11 billion meters to 24.1 billion meters. Production of chemical fibers sped up after 1988, and increased by nearly 4-fold in one decade. In addition, as one of China's main export products, export value of textile yarn, fabrics and made-up articles etc. rose from 3.5 billion dollars in 1984 to 12.8 billion dollars in 1998. By 1995, 6 years before joining WTO, China had already become the world's largest producer and exporter of textiles and clothing.

\subsubsection{Second Industrial Revolution: Mass Production of Capital-Intensive Heavy Industrial Goods (1998-)}

Rapid expansion of light industries has finally provided the required savings and profit opportunities for the development of heavy industries because it created a large enough market for energy and steel to support the mass production of energy and steel and other heavy industrial goods. Mechanization (mass production) in one segment (downstream) of the production process creates demand for the mechanization in other segments (upstream) of the production process and, ultimately, the mechanization in all segments of the entire production process and the associated industrial supply chains (Wen, 2016[43]). The mass production of labor-intensive light consumer goods in China calls for more efficient provision and distribution of raw materials, intermediate goods, machine tools, energy, locomotives, communication and transportation infrastructure, which triggered the second industrial revolution. The second industrial revolution, as happened in the middle 19-century England and late 19-century America, features the mass production (supply) of heavy industrial goods such as chemicals, cements, iron, steel, transport infrastructure, engines, machines, equipment, automotive products, ships, cars, trucks, airplanes and so on.
As shown in Fig. 4, the share of light industries in total industrial production peaked in the middle to late 1990s and the trend started to reverse downward. Between 1999 and 2011, the ratios of light industries to heavy industries in value added, employment, capital and original value of fixed assets declined rapidly (a reverse of the earlier upward trend), signaling the take-off of heavy industries in China. Nevertheless, the take-off of heavy industries since the late 1990s is different in nature from that during the planning era from the 1950 s to the 1970s. In the planning era heavy industries operated with negative profits because of the lack of a mass market, while the take-off after late 1990s was supported by large market and domestic savings.

For example, the expansion of long-distance trade created immense demand for large-scale and high-speed cargo shipping and enhanced transportation networks, which calls for the mass production of cement, steel, coal, oil and construction equipment. Since the 1990s, China's transportation networks were highly improved through build-up of expressways and the construction of a high-speed rail system. China's mileages of highway, railway and flights started to increase at a much faster speed since late 1990s, as shown in Fig. 5. First, the annually constructed expressway was $324 \mathrm{~km}$ during the Eighth-Five-Year-Plan (1988-1993), and it rose up to 1372 $\mathrm{km}$ during the first three years of the Ninth-Five-Year-Plan. By the end of 1998, China's expressway mileage ranked eighth in the world, and expressway under construction was $12,600 \mathrm{~km}$. Second, China's mileage of railway in operation reached 64.9 thousand $\mathrm{km}$ at the end of 1996. Through 6 rounds of the speed-up program from 1997 to 2007, a group of passenger trains with a speed of over 200 $\mathrm{km}$ per hour was put into operation, and the speed of freight trains reached $120 \mathrm{~km}$ per hour, 3-fold faster than the freight trains in the early 1990s. ${ }^{7}$ In addition, China started the construction of high-speed rails in 2008. By the end of 2015, China had built up the world's largest and fastest high-speed rail networks with a total length of 19 thousand $\mathrm{km}(50 \%$ longer than the rest of the world). 

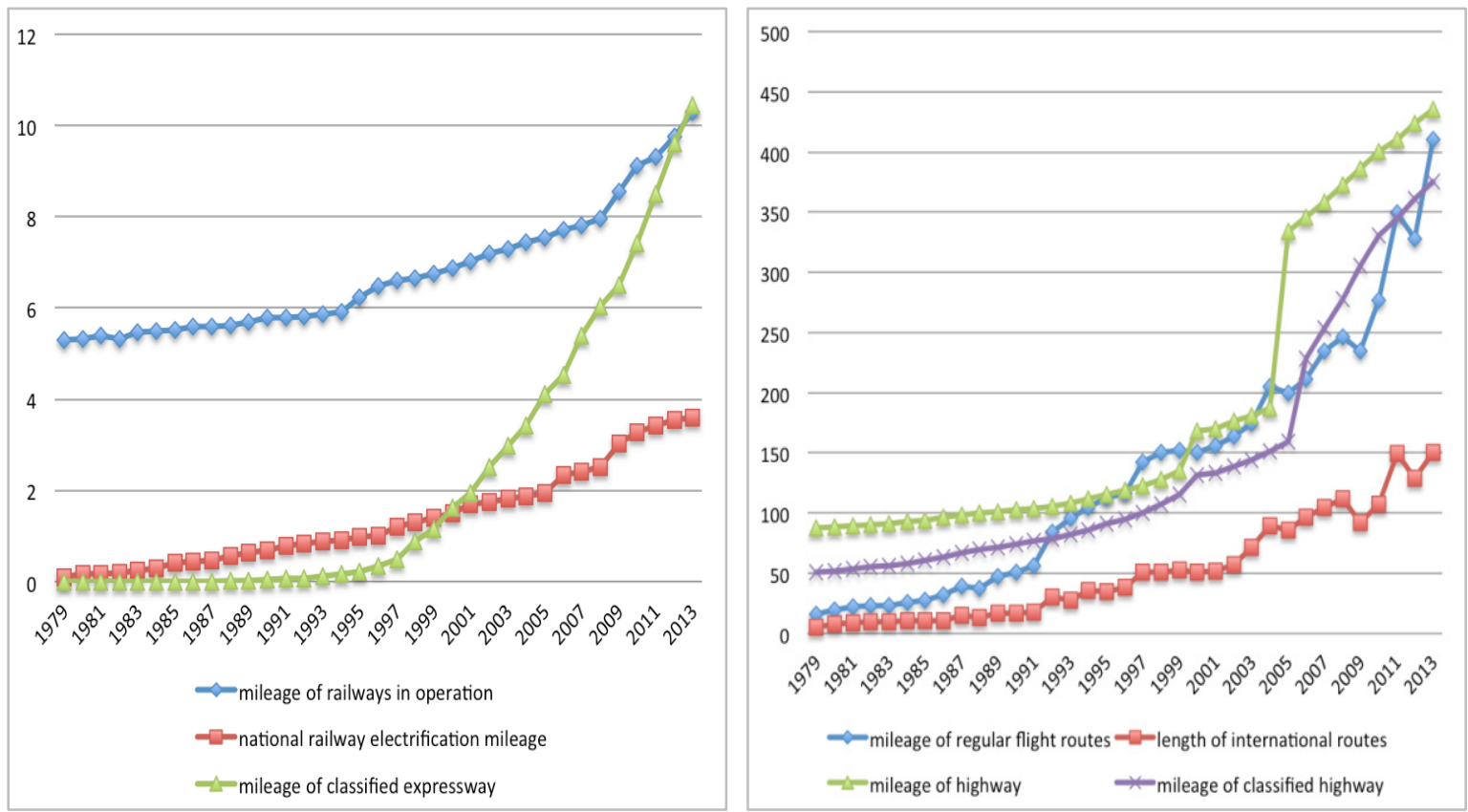

Notes: Data source is NBS, and unit is thousand $\mathrm{km}$.

Figure 5. Development of Transportation Infrastructure in China
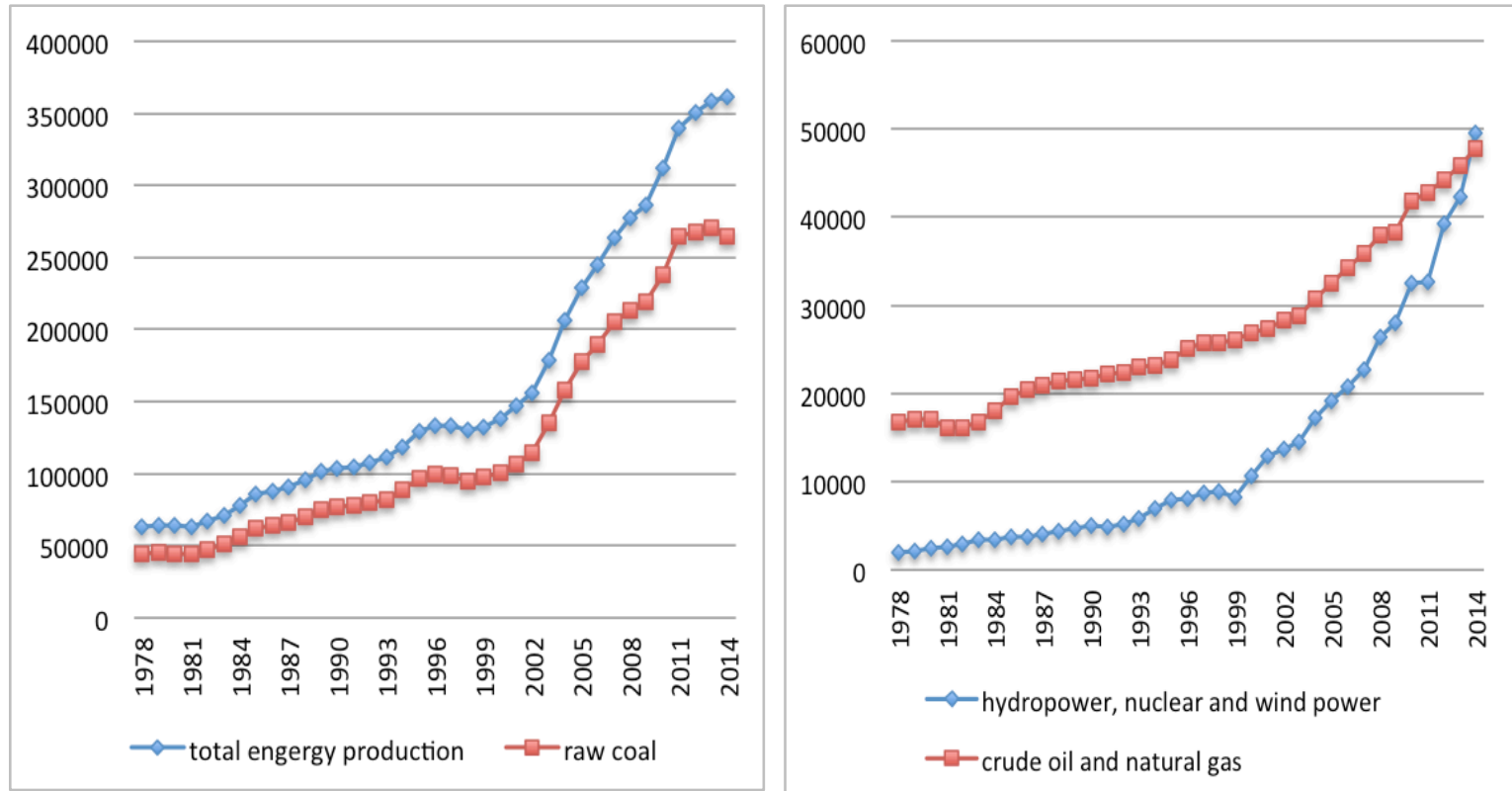

Notes: Data source is MCDB, and unit is 10 thousand tons of standard coal.

Figure 6. Energy Production in China

Rapid growth of manufacturing and long-distance transportation also requires mass production of energy. Data (Fig. 6) show that total production of energy in China rose from 630 million tons of standard coal in 1978 to 1.3 billion tons of standard coal in 1998 and sped up even further afterward. In particular, China's energy production reached a new turning point in the late 1990s and started to accelerate, marking the era of a second industrial revolution. By 2015, total energy production in China reached 3.62 billion tons of standard coal, 2.8 times as large as the production in 1998, and 5.8 times as large as the production in 1978. As China's main energy supplier, the coal industry entered an unprecedented phase of prosperity and a "golden decade" after 2002, driven by a large and rising demand for electricity, metallurgy, chemicals, building materials and other coal-consuming industries. Coal production in China increased from 1.14 billion tons in 2002 to 2.67 billion tons in 2012 at an annual growth rate of $9 \%$. In addition, growth of hydropower, nuclear and wind power in China accelerated after entering the 21 st century, accounting for an increasingly larger share in total energy production. 
Specifically, China became world's largest hydropower producer and overtook the U.S. in 2004, with an installed capacity of 100 million kW. By 2010, China's installed capacity of hydropower reached over 200 million kW.

Facilitated by the "Industrial Trinity" boom in energy, locomotive power and infrastructure, mass production of heavy industrial goods in China has expanded at an explosive rate since the late 1990s. Between 1998 and 2011, value added of heavy industries increased from 1194.3 billion yuan to 17368.6 billion yuan, at an annual growth rate of $22.8 \%$. Capital stock of heavy industries increased 3.4-fold from 3109.9 billion yuan to 10688.3 billion yuan, and employment increased from 56.39 million to 74.06 million. ${ }^{8}$ What's more, compared with value added structure in 1997 , value added share of most heavy industries rose up significantly, especially iron and steel, transport equipment, electrical machinery, electronic and telecommunication equipment. ${ }^{9}$ In contrast, value added share of light industries declined, especially for food and textile industries, even though these light industries were still growing in absolute terms.
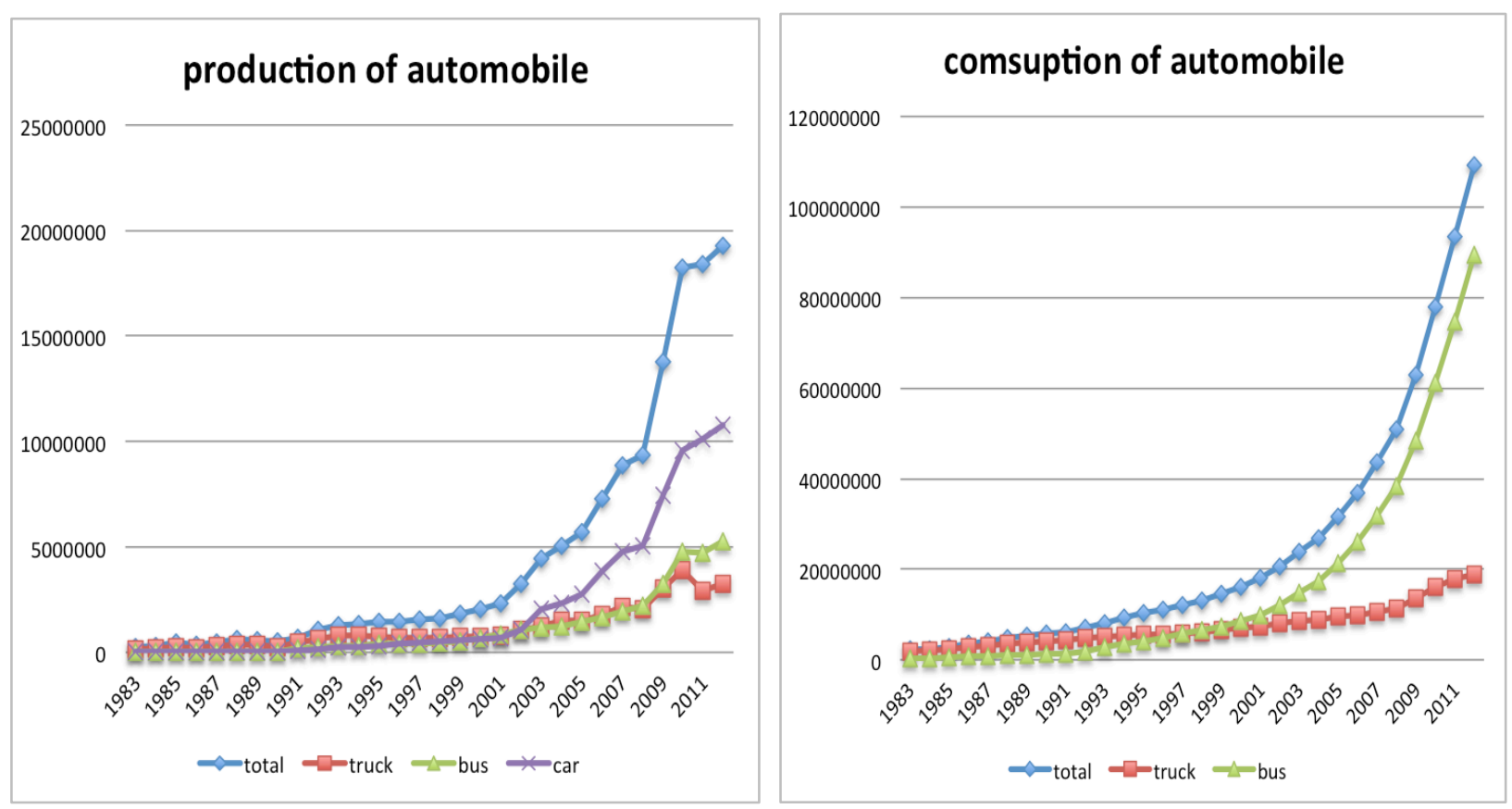

Data source: China Industrial Economy Yearbook

Figure 7. Production and Consumption of China's Automobile Industry

Fig.7 reports the production and consumption of China's automobile industry. The number of automobiles produced in China grew from 1.45 million in 1995 to 19.27 million in 2012 at an average annual rate of $16.4 \%$. The rapid growth of the automobile industry is stimulated by increasing domestic demand. Household consumption of automobiles started to rise at an even faster speed after entering the new century. For instance, the number of household-owned automobiles in 1995 was 10 million, and it rose up ten-fold by 2012. In the meantime, export of China's automobiles expanded from 17 thousand in 1995 to 1015 thousand in 2012, thanks to China's competitiveness in automobile manufacturing.

To summarize, we see that the ratio of light industries to heavy industries exhibits hump-shaped pattern since the 1978 reform under several measures, which illustrates China's reversed path of industrialization after the 1978 reform by developing labor-intensive light industries first, and then gradually upgrading to capital-intensive heavy industries with the accumulation of physical capital and human capital (skill). This pattern is consistent with the logic of the Industrial Revolution and the pattern of industrialization in other successfully industrialized countries, as shown below.

8 Data source: China Industrial Economy Yearbook and author's calculation. Capital is estimated by perpetual inventory method, in 1990 constant price. Value added is in current price.

9 Value added share of electronic and telecommunication equipment industry increased in China both from 1988-1998 and after 1998. There is a transformation from labor-intensive to capital-intensive in this industry per se throughout industrialization, as in the case of Singapore. 


\section{Patterns of Industrial Upgrading in Japan and Asian Tigers}

Japan and the "Asian tigers" are the few economies that escaped both the low- and middle-income traps successfully. In this section, we show that these economies followed the same pattern of industrial upgrading as China's by going through three developmental stages sequentially; namely, the rural proto-industrialization stage, the stage of mass production of light industrial goods, and the stage of mass production of heavy industrial goods.

\subsection{The Run-up to the First Industrial Revolution-Proto-industrialization in the Countryside}

\subsubsection{Rural Industrialization in Japan}

Most of the existing literature views the Meiji Restoration as Japan's starting point of industrialization. But the fact is that Japan's modernization started in the Edo Period (1603-1868), during which agricultural trade and rural handicraft manufacturing achieved comprehensive development because of its domestic political stability and the huge influence of China's commercial civilization in the Tang dynasty and Song dynasty. The critical difference before and after the Meiji Restoration was that the state became consciously involved in industrial policies and global market creation for domestic manufacturing after the Meiji Restoration. Thus, in the early Meiji Period (1868-1890), Japan completed its phase (stage) of global trade-oriented proto-industrialization in rural areas under the leadership of the government, analogous to China's long-distance-trade-oriented Village-Township-Enterprise boom in the 1980 s.

Specifically, due to a nation-wide commerce boom in the middle of the Edo period, Japan began to shift its commerce and craftsmen manufacturing activities from the urban areas to the rural areas in the early 1700 s since rural areas were richly endowed with raw materials, energy (hydraulic power), and cheap labor force. Smith (1988) [42] noted that the average population of 35 Japanese castle towns decreased by $18 \%$ from the 1700 s to the 1850 s, while population rose appreciably in the rural districts near these castle towns. Manufacturing, trade, transportation and other relevant non-agricultural professions were important sources of income for Japanese rural families. According to a survey of two provinces in Chōshū Domain by Japan in $1843,55 \%$ of the rural net revenue came from non-agricultural sector (Smith, 1988[42]). Japan's rural manufacturing primarily involved the production of consumer goods, such as sake, plant oil, sugar, silk, cloth and paper, aiming at long distance trade. Although most of the enterprises were small-sized, the gross output value in rural areas was huge. In the late Edo Period, most of the urban residents bought most daily necessities from the countryside. For instance, $90 \%$ of the silk products sold in
Tokyo in 1859 were made in the rural area (Smith, 1956[41]). After the Meiji Restoration, the development of commerce and handicraft manufacturing in the rural districts of Japan saw greater improvement under the help of the state to promote exports. As a result, farmers' purchasing power and demand for manufactured products also increased significantly. For example, the domestic demand for cloth tripled from 1875 to 1895 , and the rural demand grew faster than the national average (Hayami, 1998[17]). Besides, the development of rural industry and commerce helped cultivate the rural laborers' commercial spirit and manufacturing skills, preparing unified market and disciplined labor forces for the first industrial revolution in Japan.

The division of labor became increasingly important in the process of rural industrialization in Japan. By the end of the $18^{\text {th }}$ century, production was generally segmented into several independent steps and completed by different households. The proto-industrialization process created many rich peasants (gōnō). These rich Japanese peasants (gōnō) served as "rural entrepreneurs" or "intermediaries", and played the same role as the rich merchant class in England played in the 1600s and 1700s. The rich merchant class emerged in England in the 17-18 centuries from global colonization and transatlantic slave trade. They adopted the "putting-out" system to engage the rural surplus labor into nationwide handicraft manufacturing by providing raw materials, technology, market information and trade networks. Their Japanese counterparts did the same. They knew well about local market demand, product types, and labor quality (Smith, 1956[41]). These gōnō provided farmers with raw materials and tools, and sold the finished goods, which are produced "locally" but sold to remote domestic and foreign markets. Such a "putting-out" system was widespread in Japan's rural areas in the 1700s and 1800s, under which, farmers in many towns and villages produced differentiated cotton textiles in small quantities for long-distance trade. For instance, Iruma, a typical rural base for textile production in Japan, started cotton textile production in the early 1800 s and grew into one of Japan's largest cotton textile production areas in the late 1890s (Hayami, 1998[17]). The encouragement of the state for exports promotion and the distribution networks organized by the local merchants and wholesalers played a critical role in promoting rural industrialization in Japan.

\subsubsection{Rural Industrialization in Taiwan}

The agricultural by-product processing industries in Taiwan, including the sugar industry and camphor industry, began to grow in the colonial period, particularly after World War I, driven by increasing demand from the Japanese market. From 1920 to 1937, the number of food processing plants in Taiwan increased from 1,462 to 5,386, and the number of workers increased from 28000 to 49000 . The sugar industry was the pillar industry, and total granulated sugar yield accounted for $79 \%$ of the food 
processing output in 1914 , and for $83 \%$ in $1929 .{ }^{10}$ Most of the processing factories were small-sized manual workshops with less than 30 workers per firm, and were located in the rural area due to the availability of raw materials and cheap surplus labor. In 1930, rural workforce accounted for $62.6 \%$ of total manufacturing employment, and for $84.8 \%$ of total mining employment (Ho, 1979 [20]).

More importantly, the rural industry began to boom in Taiwan in the 1950s, led by the government's effort to promote industrialization. Nonfarm income accounted for $25 \%$ of total income for rural households in 1962, and increased to $43 \%$ in 1975 . The number of rural workers engaged in farming decreased from $73 \%$ to $54 \%$ from 1956 to 1966 , and meanwhile 275000 new employees entered the manufacturing industry and $46 \%$ of them entered rural manufacturing industry. As a result, the average annual growth rate of rural manufacturing employment reached $7.2 \%$, much higher than in the urban areas. Tab. 1 lists the rural and urban distribution of employment in Taiwan. The mining, manufacturing, construction, commerce, transportation, and communications industries all witnessed a relatively more rapid growth of employment in rural manufacturing than urban manufacturing during the initial period of industrialization from 1956 to 1966 .

However, the rural industrial enterprises were much smaller in size compared with its urban counterparts. For example, a rural industrial enterprise had only 15 workers on average, while 50 workers were employed by each urban industrial enterprise. But rural manufacturing employment grew faster than urban manufacturing employment, since most firms in rural areas produced labor-intensive products, such as food, textile and furniture, and made full use of rural surplus labor. For example, from 1956 to 1966 , the average annual growth rate of employment in Taiwan's rural textile industry was $8.6 \%$, while that in the urban textile industry was $5 \%$. As a result, the share of rural manufacturing employment in total manufacturing employment increased from $37.2 \%$ to $41.3 \%$. By 1971, the ratio of rural manufacturing employment to total manufacturing employment rose to $50 \%$, and the ratio of rural manufacturing value added to total manufacturing value added reached $48 \%{ }^{11}$

A full-fledged proto-industrialization in rural Taiwan greatly fermented the national market and expanded supply chains and commercial distribution networks, making Taiwan well prepared for its mass-production-based industrial revolution in the next stage.

\subsection{Transition from Labor-Intensive Industrialization to Capital-Intensive Industrialization}

10 Data from: Industrialization in Taiwan before the Retrocession by Zhang Zonghan. Taipei: Linking Publishing, 1980. Tab.10 in p25-26. 11 Date from Ho (1979).

\subsubsection{South Korea's Industrial Upgrading 12}

South Korea followed the same sequence of development by upgrading industries sequentially from light industry to heavy industry, from labor-intensive industry to capital-intensive industry, and from consumer-goods production to capital-goods production. In particular, South Korea's light industry experienced a prosperous development after WWII from the early 1950s to the middle 1970s, which paved the way for a boom of heavy industrialization since the late 1970s.

In the $1950 \mathrm{~s}$, South Korea began to develop low-tech and quick-return labor-intensive industries, such as food processing, textiles, clothing, leather and shoemaking. The South Korean government seized the post-war opportunity of a large U.S. market and actively carried out an export-oriented industrial policy by taking advantage of its cheap labor force. Driven by the huge market demand abroad, South Korea's light industrialization took off.

Tab. 2 shows the structure of South Korea's manufacturing value added. The value added of South Korea's light industry accounted for more than $80 \%$ of the gross manufacturing value added during the years from 1953 to 1960, and meanwhile the value added of food, beverage and tobacco industries accounted for more than $30 \%$ of the gross manufacturing value added. Also, the value added of textile, garment, footwear and leather products industries accounted for more than $30 \%$ of the gross manufacturing value added during the twenty year period from 1953 to 1973 . According to the employment structure of the Korean manufacturing industry (Tab. 3), from 1961 to 1970 , the ratio of light industrial labor force to the aggregate manufacturing labor force in South Korea exceeded $74 \%$. From the 1960 s to 1980 s, employment in the textile, garment, footwear and leather products industries accounted for over $30 \%$ of total labor force, during which period these industries dominated Korean production and exports. From 1970 to 1980, the value added of textile and leather products increased further from KRW134.4 billion to KRW1.9765 trillion. The average annual growth rate reached $30.8 \%$ in nominal terms; the gross output of textile and leather products increased from KRW521.7 billion to 10.1454 trillion, with an average annual growth rate of $34.7 \%$ in nominal terms. From 1962 to 1980 , the export of textile products increased from USD2.216 million to USD2.197558 billion, with an average annual growth rate of $46.7 \%$; the export of garment products increased from USD1.118 million to USD2.94685 billion, with an average annual growth rate of $54.9 \%$.

With such an explosive growth in South Korea's light industry, it created a huge demand for raw materials, intermediate products, machine tools, energy, and

12 Due to the lack of early-time data, we do not have knowledge about the proto-industrialization in South Korea in pre-war times. 
transportation infrastructure, as well as ample domestic savings, making it possible to support a capital-intensive heavy industrialization. With the support of the government, South Korean kick-started a heavy industrialization by late 1970 s by engaging in the mass production of steel, coal, metals and metal works, machine tools, automobiles, ships, traffic equipment, electronics, and petrochemicals.

During the ten-year period from 1980 to 1990 , for example, South Korea's industrial value added increased from KRW8.5188 trillion to KRW48.6409 trillion, with an average growth rate of $19 \%$ per year in nominal terms. In particular, the value added of traffic equipment manufacturing industry increased from KRW450.6 billion to KRW5.8845 trillion, with an average annual growth rate of $29.3 \%$; the value added of metals and metal works increased from KRW8.816 billion to KRW6.9935 trillion, with an average annual growth rate of $23 \%$. ${ }^{13}$ As shown in Tab.2, from 1973 to 1990 , the ratio of heavy industrial value added to the total manufacturing value added increased from $27.6 \%$ to $47.9 \%$; in particular, the share of metals and metal works, machinery and transport equipment manufacturing increased from $14.5 \%$ to $33.6 \%$. It can be seen from the employment structure in Tab. 3 that the portion of labor force engaged in heavy industry to the entire manufacturing industry was equal to $25.7 \%$ in 1970 , increased to $40.8 \%$ in 1990 , and rose further to $50.8 \%$ in 2006.

Such a rapid industrial upgrading is also reflected in South Korea's exports. Food processing industry was the main export industry of South Korea in the early 1960s, which accounted for $36 \%$ of the total exports in 1961 . Afterward, textile export grew rapidly and soon outstripped food export. From 1962 to 1968, the export share of textiles, garments, shoes and bags increased from $6.3 \%$ to $40.7 \%$, staying above $35 \%$ all the time until 1980 .

A successful light industrialization prepared the foundation to promote heavy industrialization in South Korea. In the late 1970s, South Korea established steel and shipbuilding industries, which were listed among South Korea's top ten export industries in the 1980s. South Korea's semiconductor, computer and automobile industries saw fast development in the late 1980s, and ranked among South Korea's top ten export industries in the 1990s. The exports of South Korea's heavy industrial products accounted for $13.1 \%$ in 1975 , increased to $24.3 \%$ in 1980 , and rose to $41.6 \%$ in 2000 . It is thus clear that the major export items of South Korea went through a transformation from labor-intensive products and light industrial products to capital-intensive and technology-intensive products.

13 Data from Statistics Korea

\section{Patterns of Industrialization for Countries Stuck in Different Income Traps}

\subsection{Middle-income Trap and Premature Heavy Industrialization}

After World War II, Latin American countries and many south Asian countries adopted the import substitution industrialization (ISI) strategy. This strategy not only favors self-sufficiency in the production of consumer goods and intermediate products, but also focuses particularly on heavy industrial products and effectively shuts down the international market.

Once all imported goods were substituted out by domestic production, these countries effectively imposed severe limits not only on the degree of specialization but also on the size of markets for their own products. In contrast, the Asian tigers implemented an export-oriented strategy in the late 1950 s by specializing in light-consumer goods production aimed at international markets. This export-oriented development strategy not only fully utilized comparative advantage, greatly expanded their market for mass-produced goods and thus significantly reduced the average cost of production, but also gained invaluable experience in discipline and quality controls of production through international competition. In addition, importing foreign technologies can improve the speed and quality of labor-intensive mass production and it helped instead of hindered these countries' speed of climbing up the technology ladder. Under ISI, in contrast, Latin American countries' technology progress has slowed down significantly and they entered the stage of heavy industrialization prematurely without fully developing their labor-intensive industries. Since heavy industries are capital intensive and cannot absorb surplus labor as effectively as light industries, Latin American countries experienced jobless urbanization that featured massive slumps in the cities. As a result, these countries suffered from huge financial burdens to finance their non-competitive heavy industrialization, modern infrastructure build-up, and social-political problems due to high unemployment.

Premature heavy industrialization goes against the logic of the Industrial Revolution. Mass production of heavy industrial goods is not profitable without a mass market to absorb the huge fixed costs of investment and R\&D expenditures. The very market for heavy industrial goods is precisely created by the light industries. First of all, most heavy industrial goods, such as cement, steel, metal, petrochemicals, machine tools and equipment were not final consumer goods, but intermediate goods or factors of production for final goods. Thus, there could never be sufficient demand for heavy industrial products unless consumer goods production reached a critical scale. Second, jumping to the stage of heavy industrialization 
goes against a country's comparative advantage in abundant cheap labor. In addition, economic efficiency will be seriously reduced when governments try to support their unprofitable heavy industrial enterprises by subsidies and price distortions.

Data show that at a similar level of per capita income, the capital-output ratio was about 1.7 in Taiwan and South Korea from 1960 to 1969 , while this ratio reached 3.0 in Guatemala, Ecuador and Paraguay, and 3.5 in Bolivia, Columbia and Peru (Balassa, 1971[5]). This suggests that Latin American countries' have over-invested in heavy industries.

Fig. 8 shows a cross-country comparison in the share of heavy industrial value added. The data of industrial value added is from CEPII, while that of real GDP per capita is from PWT9. The figure compares the share of heavy industry in various countries using South Korea (the blue diamond) as a benchmark. Heavy industry includes metal and metal product industry, machinery industry, traffic equipment manufacturing industry and the petrochemical industry. Based on full-fledged development of light industries before 1970s, the share of South Korea's heavy industrial value added in total manufacturing value added rose from $28 \%$ in 1970 to $47.9 \%$ in 1990 , while its per capita income rose rapidly from $\$ 2000$ to $\$ 12,000$. In contrast, the share of heavy industrial value added in many Latin American and Eastern European countries was 10 to 30 percentage points higher than South Korea's at comparable income levels. Specifically, in Brazil (1963; 1990), Ecuador (1990), Bolivia (1980), Mexico (1989), Venezuela (1980), Argentina (1985), Bulgaria (1997), Poland (1981), Bosnia and Herzegovina (1991), Turkey (1981), and Azerbaijan (2001), the share of heavy industrial value added was 10 percentage points higher than that in South Korea; in Azerbaijan (2005), Egypt (1991), Venezuela (1980), Ecuador (1994), Peru (1985) and Bolivia (1988), the share of heavy industrial value added was 20 percentage points higher than that in South Korea. Over-investment in their heavy industries at per capita income level comparable with that in South Korea (in blue diamond) hindered these countries' economic growth and industrial upgrading. Today, the quality and scale of South Korea's heavy industry is in a par with that of Germany and Japan precisely because it did not rush into heavy industrialization at its early developmental stage in the 1960 s and 70 s.

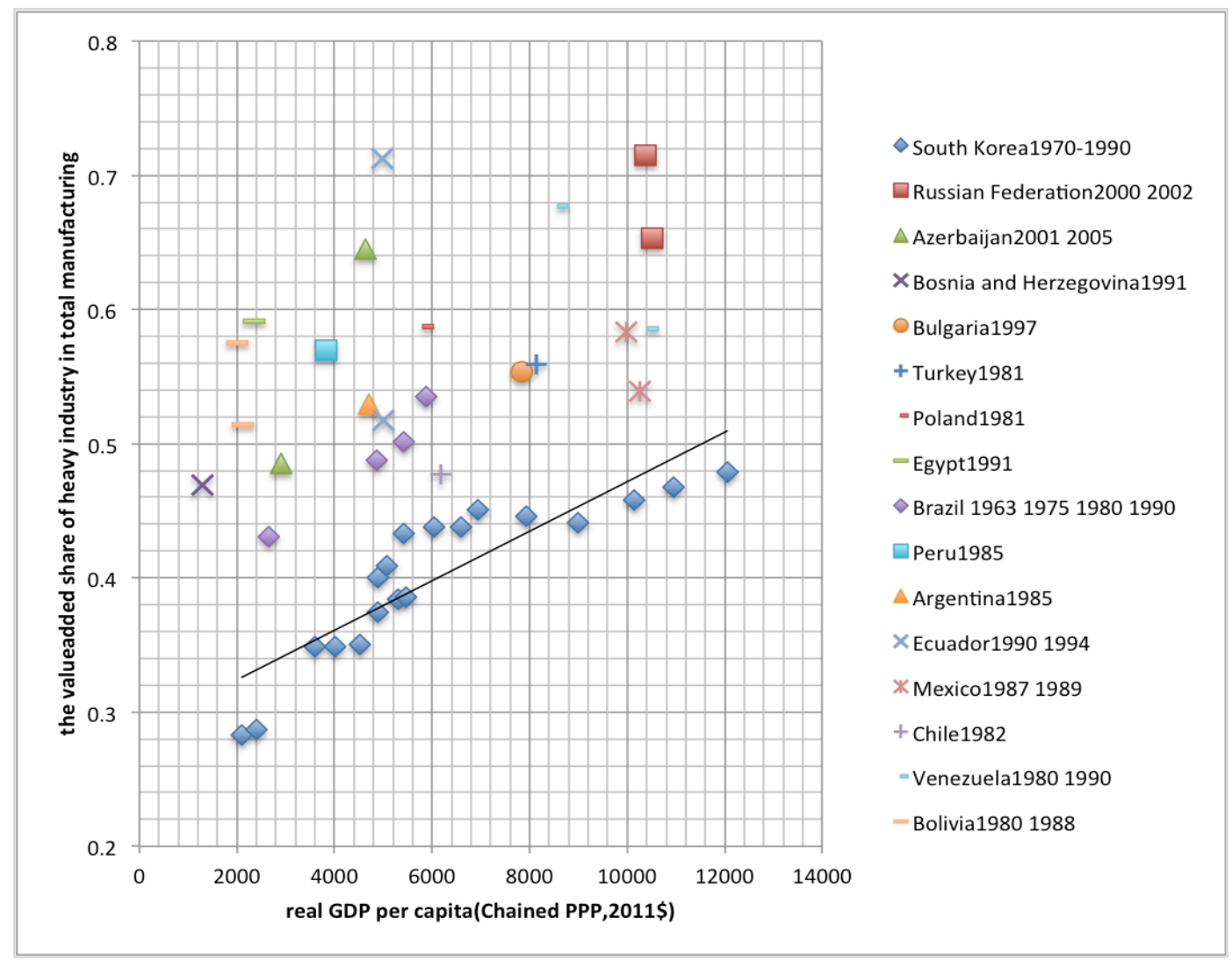

Data sources: CEPII Database, Statistics Korea, PWT90, Baer and Guilhoto (1987)[6] and Authors' Calculation.

Figure 8. Value Added Share of Heavy Industries across Countries 
In other words, countries in Latin America and Eastern Europe failed to fully develop their labor-intensive industries before embarking on the path of heavy industrialization. This leap-frog development strategy deprived of their comparative advantages and, as a result, of their continuous industrial upgrading. This is not a problem of the state capacity per se, but rather a problem of lack of knowledge of the fundamental mechanisms of the Industrial Revolution (Wen, 2016 [43]). However, the Washington Consensus misdiagnosed the problems of the ISI strategies and recommended instead the recipe of "privatization, marketization, liberalization, deregulation and democratization" in the 1980s and 1990s. As a result, "premature deindustrialization" took place in these economies and further enervated economic growth, making these economies stuck in the middle-income trap. Fortunately, South Korea and other Asian Tigers did not subscribe themselves to the Washington Consensus and they thrived, as China also did after its 1978 economic reform.

If we define an economy's degree of industrialization as the share of its nonagricultural sectors' value added in GDP (including manufacturing and services) relative to that in the U.S. (as in Lin and Fu, 2016[27]), and its living standard as per capita GDP relative to that in the U.S., then the success and failure of industrial upgrading due to correct or incorrect industrial policies can be presented clearly in the following figures.

Using data from the GGDC 10-sector database and Maddison project database, we construct a relationship between relative living standard and the path of industrial upgrading measured by the corresponding share of nonagricultural value added from 1950 to 2010 , based on cross country data. If a country's industrial policy is correct, then as its non-agricultural value added increases (relative to the US level), its living standard would converge rapidly to the US level. However, if a country's industrial policy is incorrect, such as by engaging in premature heavy industrialization, then its living standard would fail to converge to the US level, which in turn would hinder its industrial upgrading process. The result is random spider-web like relationship between living standard and industrialization, instead of a simple monotonic relationship. To conserve space, we pick 3 countries in Asia and 3 in Latin America.

Fig. 9 shows the relationship between living standard and industrial upgrading in South Korea, Taiwan China, and People's Republic of China, respectively. Without exception and despite significant differences in political systems among the three Asian economies, these economies show dramatic income convergence to the US level driven by successful industrial upgrading. For instance, real income per capita in South Korea relative to the U.S. rose from $10 \%$ in 1963 to over $70 \%$ in 2010 as the relative nonagricultural value-added share increased from $78 \%$ to $97 \%$. Similarly in Taiwan, as the nonagricultural value added share relative to the US increased from $74 \%$ in 1860 to $98 \%$ in 2010 , its per capita income level relative to the US rose exponentially from $12 \%$ to $72 \%$. China's case is more interesting. Before the economic reform in 1978, China's push for industrial upgrading did not result in the rise of living standard relative to the US; namely, its nonagricultural value-added share relative to the US rose from $18 \%$ around 1950 to $60 \%$ in 1978 , its living standard relative to the US remained at $5 \%$, despite significant improvement in the degree of industrialization especially heavy industrialization. However, after the economic reform, China's per capita income converged rapidly to the US level, rising from $5 \%$ to $27 \%$ as its degree of industrialization relative to the US rose from $60 \%$ to $90 \%$. So China has successfully risen from a low-income country to a middle-income country.

Judged by the experience of South Korea and Taiwan, under successful industrial upgrading, as the nonagricultural value-added share relative to the US rose from $90 \%$ to $98 \%$, its per capita income would increase from around $25 \%$ of the US level to more than $70 \%$ of the US level. This suggests that China's per capita income should be able to increase further from $27 \%$ of the US level to more than $70 \%$ of the US level in the next 30 years it its nonagricultural share of value added can rise from the current $90 \%$ of the US level to about $98 \%$ of the US level. 

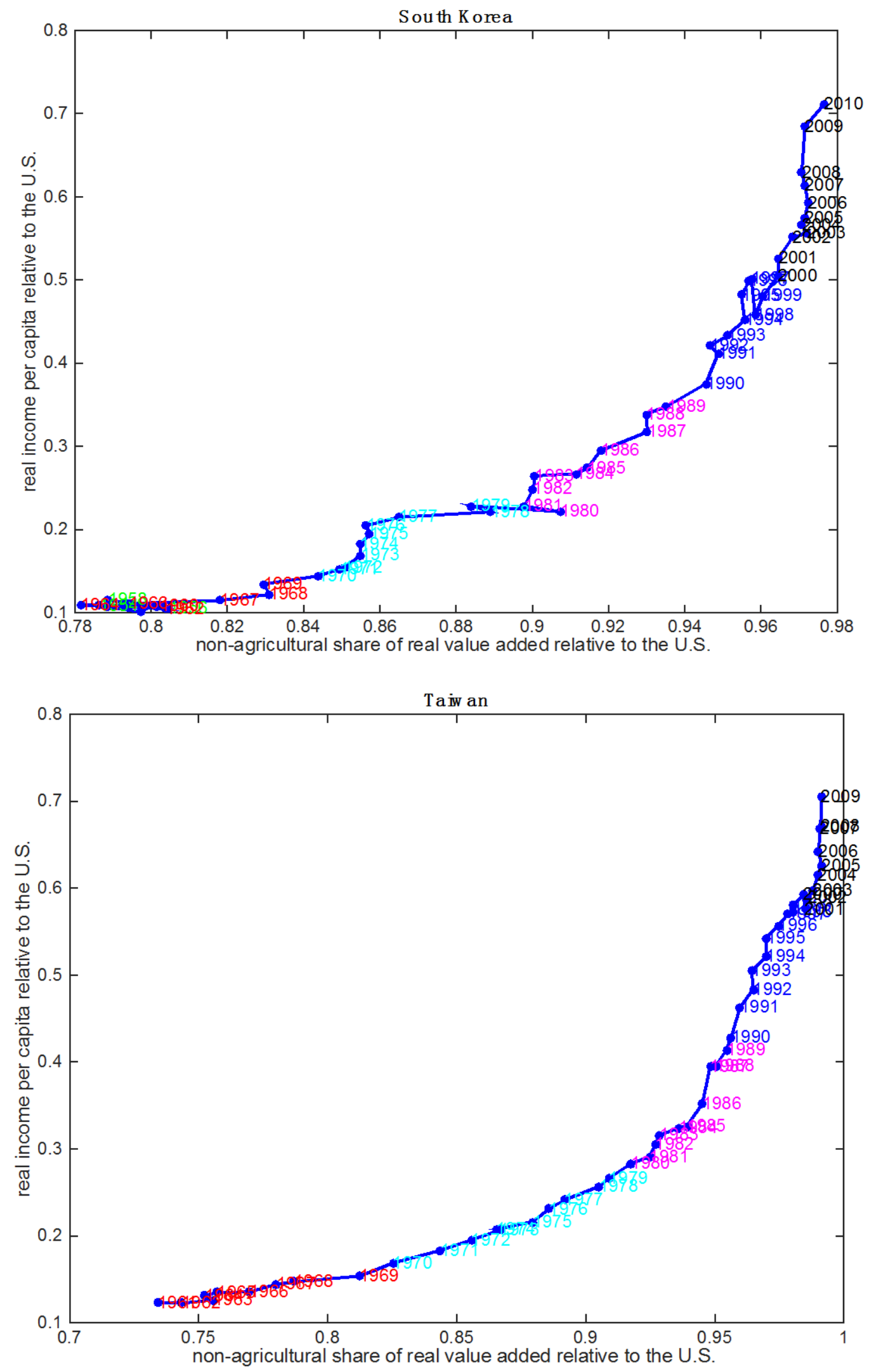


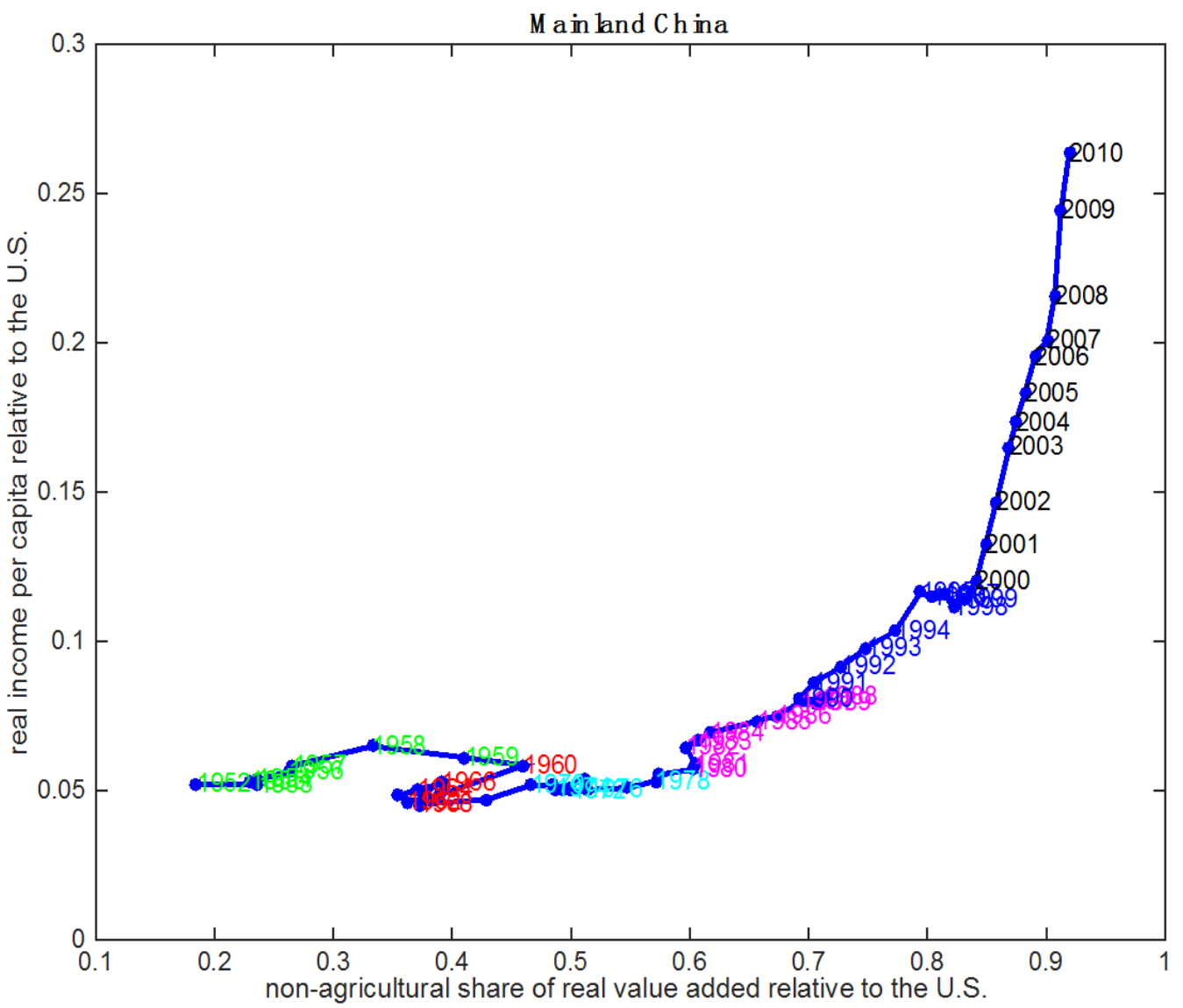

Figure 9. Successful Convergence in South Korea, Taiwan and Mainland China

Now let us look at the three Latin American countries in Fig. 10, namely, Argentina, Chile, and Columbia, respectively. None of them demonstrates the smooth income convergence and industrial upgrading exhibited by the three Asian economies. In particular, as middle-income countries, Argentina started in the late $1950 \mathrm{~s}$ a living standard of $55 \%$ of the US level in per capita income, with nonagricultural value-added share at $89 \%$ of the US level. However, during its ISI heavy-industrialization period, although its nonagricultural value-added share rose from $89 \%$ to $92 \%$ of the US level, its per capita income relative to the US bounced around and eventually declined by 10 percentage points, from $55 \%$ in 1958 to $45 \%$ in 1980. After the global oil shock and especially after subscribing to the Washington Consensus, it deindustrialized with nonagricultural value-added share regressing from $92 \%$ of the US level to $89 \%$ of the US level, and its corresponding per capita income declined from $45 \%$ of the US level in 1980 to below $30 \%$ of the US level in 2000 . The cases of Chile and Columbia are not much different, all showing trapped in the middle income level when their nonagricultural value-added share reached about $90 \%$ of the US level (where China is at now). Judged by these graphs, none of these Latin American economies show clear sign of escaping the middle-income trap, especially compared with the momentum of income growth in China at the same $90 \%$ level of industrialization relative to the US. 

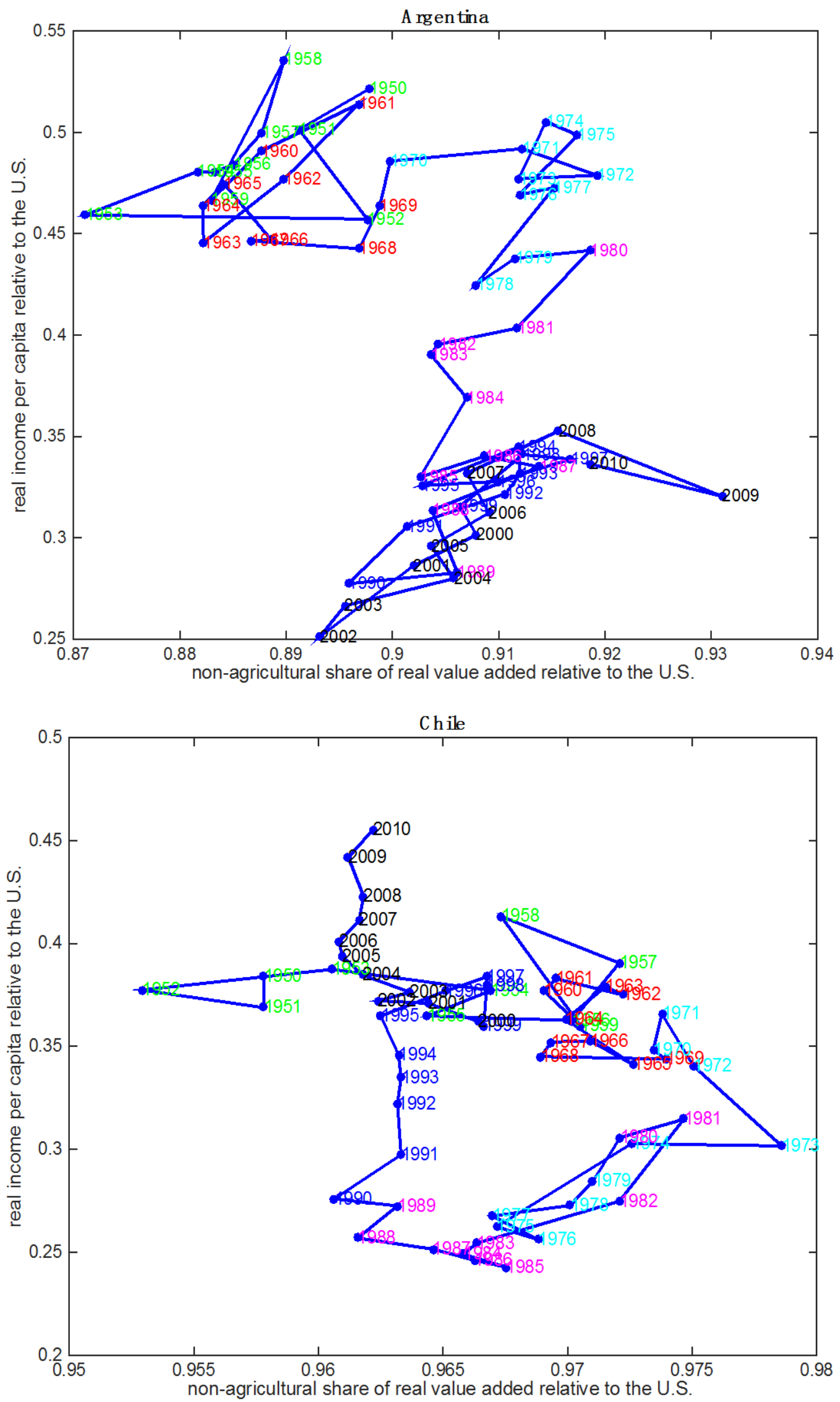


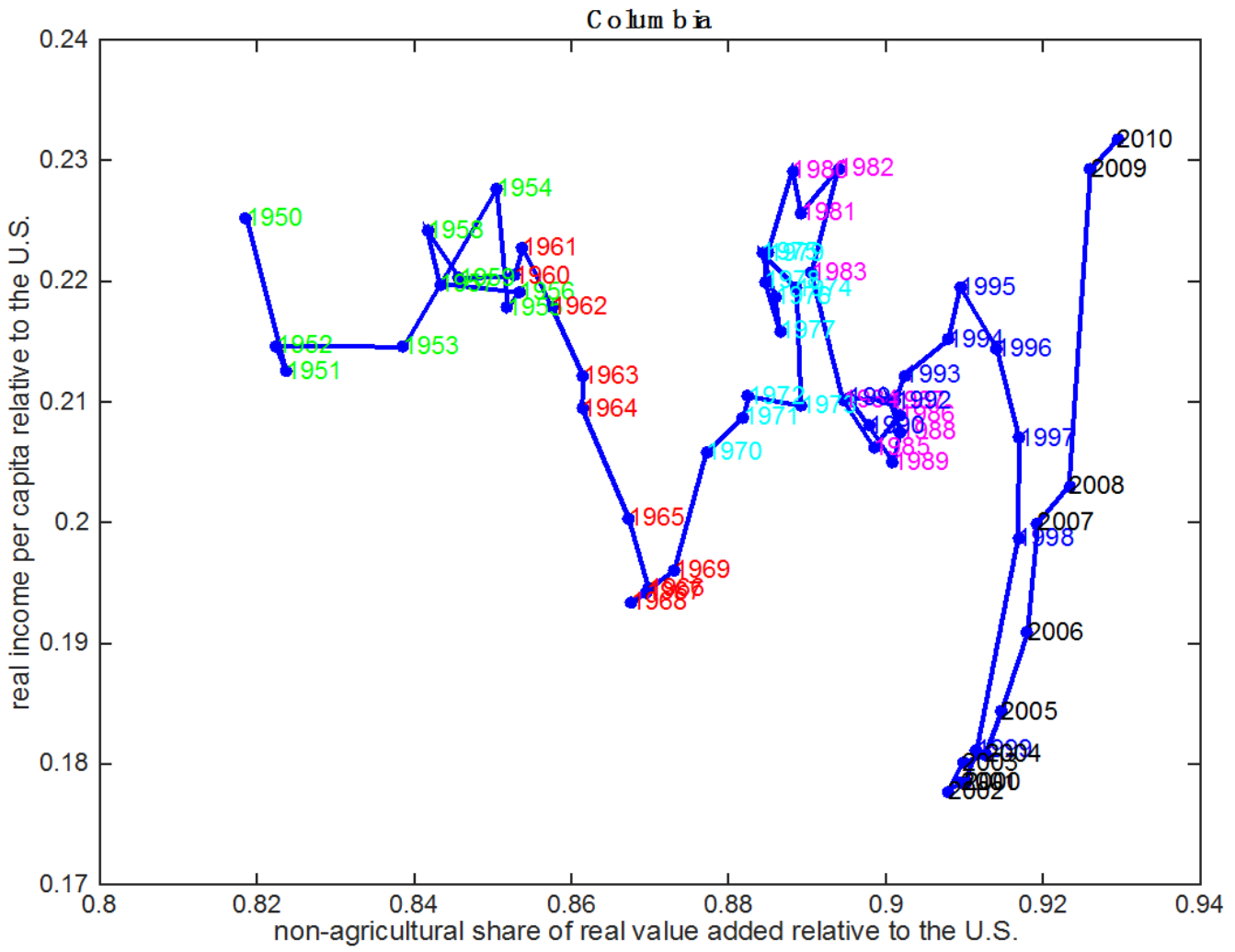

Figure 10. Trapped Latin-American Countries

\subsection{Poverty Trap and Lack of Rural Proto-Industrialization}

Most economies in Africa (especially Sub-Saharan Africa) are stuck in the poverty trap because of lack of sufficiently high economic growth. These impoverished countries rely on exporting agricultural products, minerals and other natural resources in exchange for foreign industrial goods. Since independence, many African countries have tried to industrialize. But various developmental policies have failed because neither the Import Substitution Industrialization policy nor the Washington Consensus is the right recipe for low-income countries to escape the poverty trap.

China's growth miracle sheds light on the development problem facing African countries. With per capita income below one third of Sub-Sahara African level in the late 1970 s, China is now the world's largest manufacturing powerhouse, thanks to its market-oriented reform and correct sequence of marketization. In particular, the Chinese experience suggests that for impoverished agrarian societies like Sub-Saharan African countries, the most efficient way to promote industrialization and development is to start from rural areas and produce primitive consumer goods locally for long-distance trade utilizing rural surplus labor. Rural proto-industrialization serves to create conditions for kick-starting an industrial revolution by raising farmers' income without jeopardizing food security. This process is also critical for market creation at the micro level.
Instead of promoting rural proto-industrialization like China did in the 1980s and 1990s, most Sub-Saharan African countries tried to develop by exporting mineral resources, or by setting up advanced heavy industries that are not viable or competitive in the world market. Yet their comparative advantage lies in abundant cheap labor, which can be fully utilized only through labor-intensive industrialization starting at the bottom in the countryside.

Cross-region comparisons imply that rural proto-industrialization is quite underdeveloped in Sub-Saharan Africa. The RIGA database from FAO provides household survey data on rural income-generating activities for several developing countries, based on which we can calculate and compare the share of rural industries in employment and income across countries. Vietnam is picked as our benchmark, as it has been growing very fast since the 1990s and has managed to escape the poverty trap in the last 20 years. Also, Vietnam's data is available in more than one year, so we are able to construct its rural manufacturing labor share in different income levels by interpolation and extrapolation. Although China is not included in the RIGA database, comparable index could be generated using data from China NBS. Thus, whenever possible we also use China as another benchmark to compare with the economies stuck in the poverty trap.

First, we construct manufacturing employment share in total rural workforce based on RIGA-L datasets, which provide information about rural labor participation in proto-industries. As shown in Fig. 11, China's rural 
manufacturing labor share increased rapidly from $5.8 \%$ in 1983 to $8.5 \%$ in 1988 . Rural manufacturing labor share in Vietnam also rose significantly from 1998 to 2002. In comparison, manufacturing employment share in the total rural workforce of Ghana and Nicaragua is lower than Vietnam by over $2 \%$, and lower than China by over $3 \%$ at comparable income levels. Similarly, manufacturing employment share in total rural workforce of Nigeria and Tajikistan is lower than Vietnam by over 3\%, and lower than China by over $4 \%$ in comparable income levels.

Second, we use RIGA-H datasets to calculate the manufacturing participation rate of rural households. A rural household is defined as an participant in manufacturing activity if at least one of the household members participates in manufacturing activity. Fig. 12 shows that manufacturing participation rate of rural households in the poverty-trapped economies is much lower than Vietnam. For instance, the participation rate in Malawi, Ghana, Uganda, Niger, and Nicaragua is 5 percentage points below that of Vietnam at comparable income levels, and the participation rate in Ethiopia, Tanzania, Nigeria and Kenya is 8 percentage points below Vietnam in comparable income levels. Similarly, the total manufacturing participation rate of rural households, including both wage employment and self-employment, in these economies is also significantly lower than Vietnam, except for Niger.

Furthermore, Fig. 13 shows that the rural-manufacturing income as a share of total rural household income is lower in the economies trapped in poverty than in Vietnam, and it is much lower than in China at comparable income levels. The case of China is striking: Induced by a rapid expansion of manufacturing (proto-industrial) activities in rural areas in the 1990s, manufacturing income share of rural households in China rose sharply from $10 \%$ in 1990 to $21 \%$ in 1997. In comparison, manufacturing income share of rural households in Ethiopia, Nigeria, Tanzania, and Kenya is much lower than China and even lower than Vietnam by 5 percentage points.

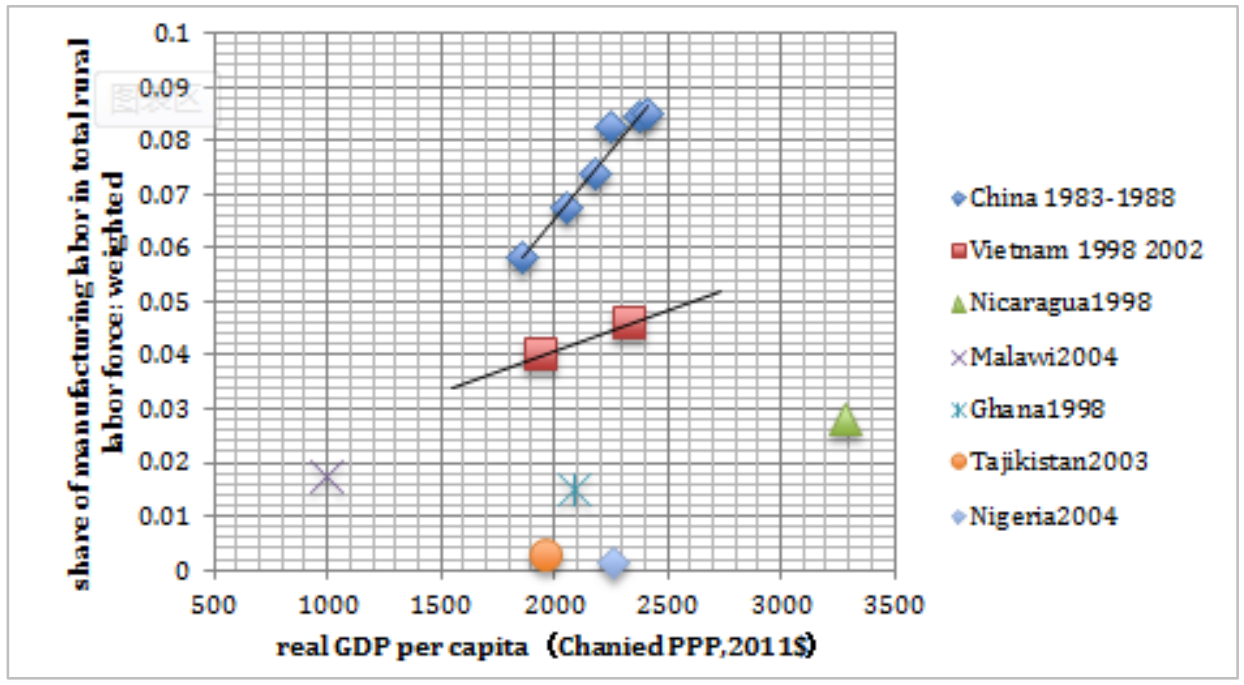

Sources: RIGA Database, China NBS, PWT9.0, and Authors' Calculation

Figure 11. Labor Share of Rural Industry across Countries

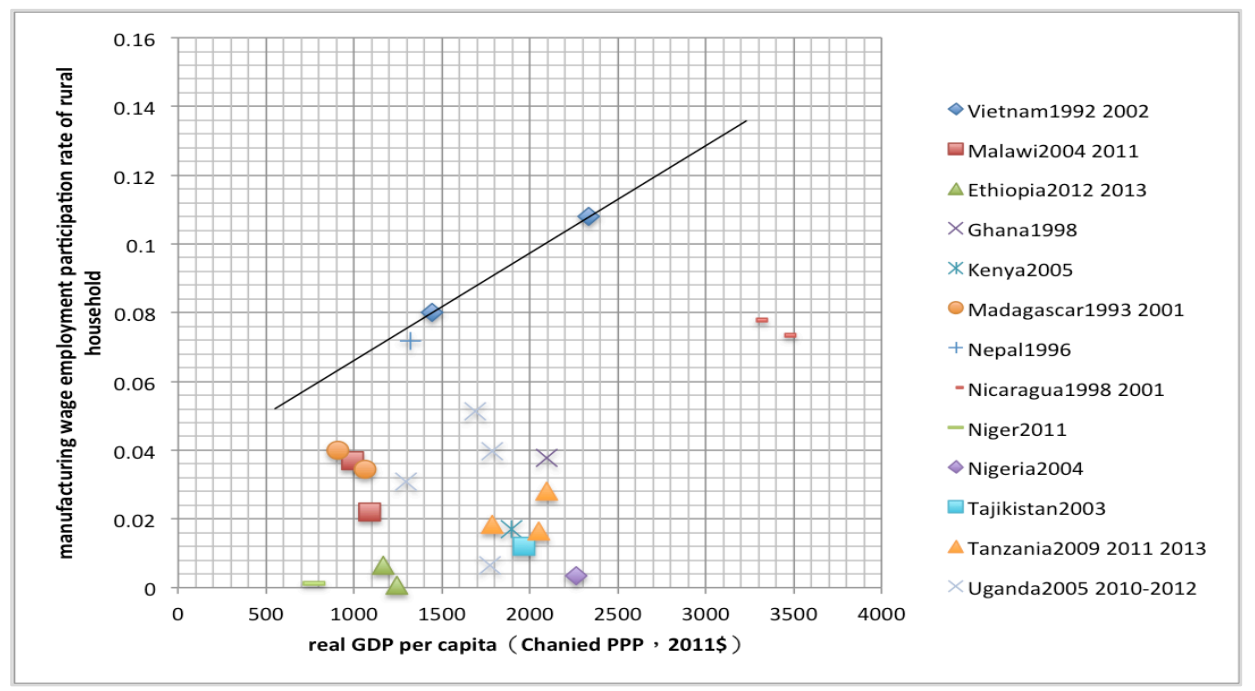




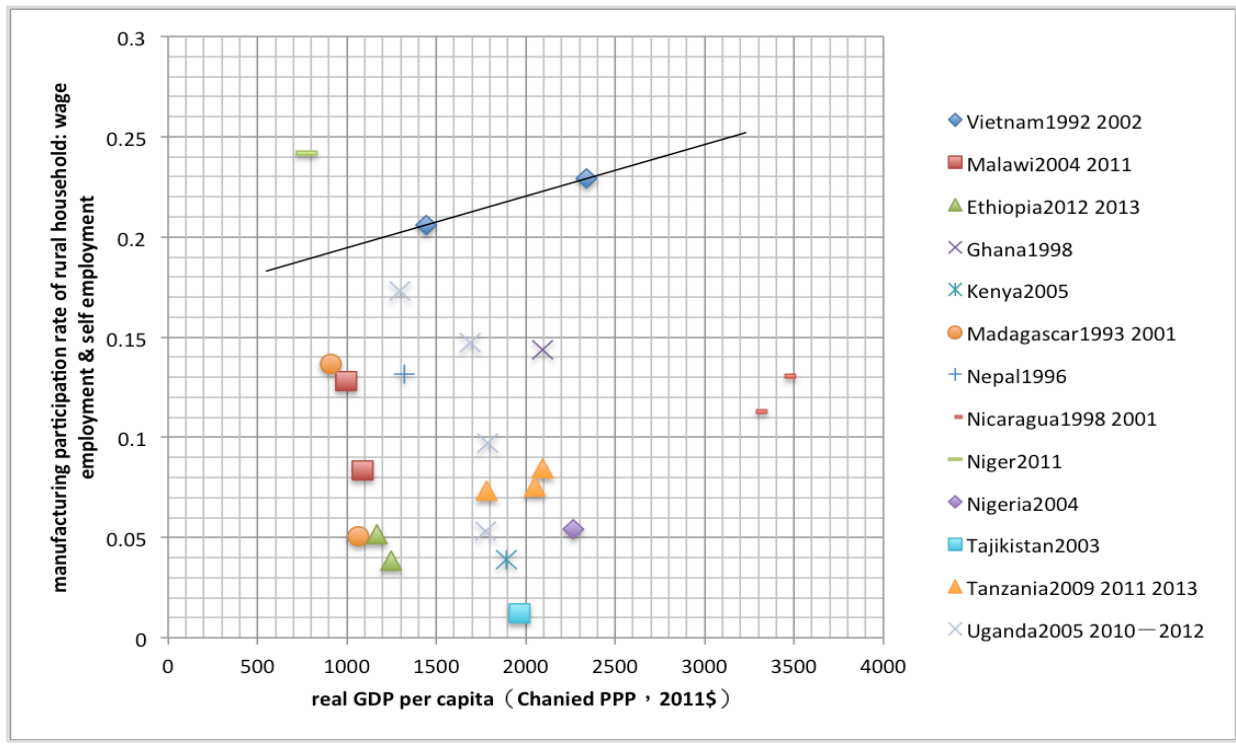

Data sources: RIGA Database, China NBS, PWT9.0, and Authors' Calculation

Figure 12. Rural Household Participation Rate in Manufacturing across Countries

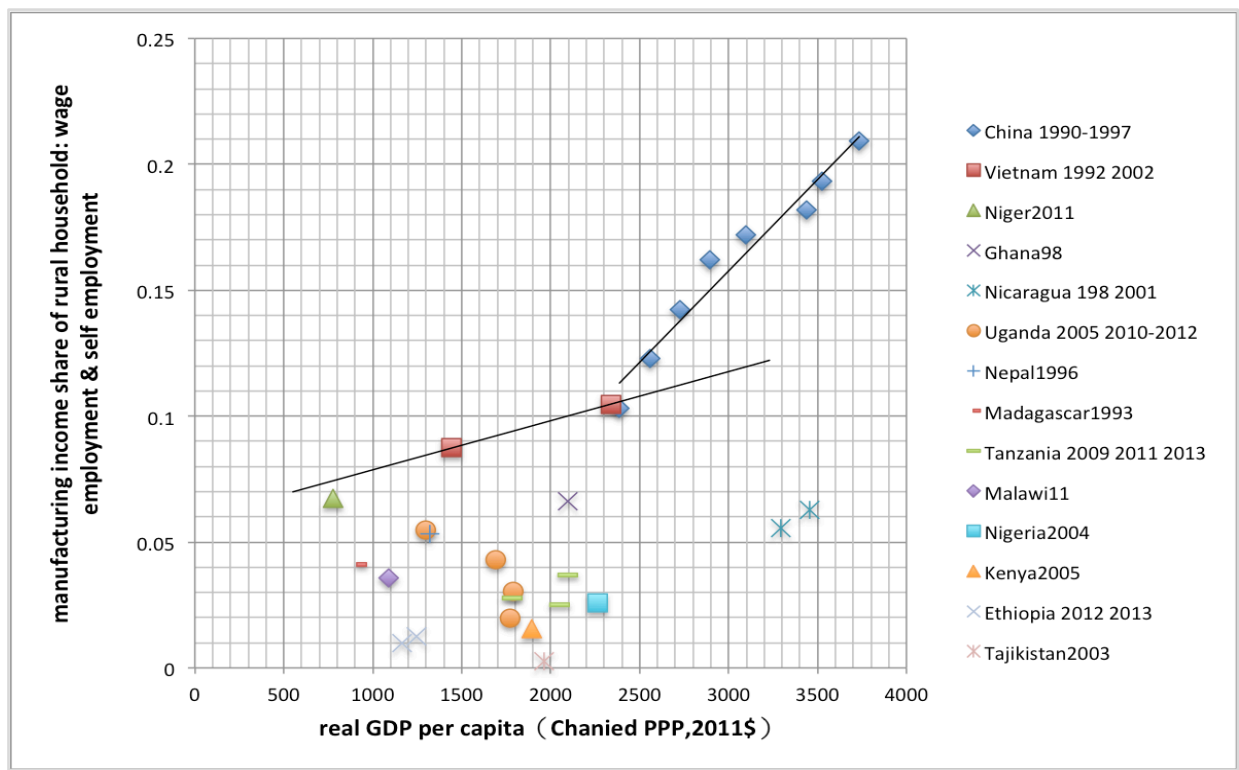

Data sources: RIGA Database, China NBS, PWT9.0, and Authors' Calculation

Figure 13. Manufacturing Income Share of Rural Households across Countries

\section{Conclusions}

This paper dissects China's patterns of economic development both before and after its 1978 economic reform, and it discusses why a few Asian countries have been able to escape the low- and middle-income traps and grow into high-income economies, while many market-economies (especially the Latin American and Eastern European countries) have been unable to do so despite being endowed with richer natural resources, more favorable geopolitical locations and a much higher degree of institutional conformation with the Washington Consensus in terms of "marketization, privatization, liberalization, deregulation, and democratization."

Our empirical evidence seems to defy the new institutional theories proposed by North (1991) [32] and Acemoglu et al. (2001)[1] about the mechanisms of economic development, and it supports instead the New Structural Economic Theory proposed by Justin Lin (2011, 2013) $[25,26]$ and the New Stage Theory proposed by Yi Wen (2016) [43]. Lin and Wen's theories view political institutions as largely endogenous to economic development and are thus not the prerequisites to development. They instead argue that the key to development is not just market but, more importantly, correct industrial policies pushed by capable governments. 
Consistent with the views of Lin $(2011,2013)[25,26]$ and Wen (2016)[43], we find that China's rapid industrialization after the market-oriented reform was mainly because it had found and followed the same correct sequence of development as Japan's and the Asian tigers' through gradual industrial upgrading from rural areas to urban areas, from light industries to heavy industries, from labor-intensive manufacturing to capital-intensive manufacturing, and from technological imitation to innovation. Market competition is surely critical in such an evolutionary process but pure market forces alone cannot do the job for two reasons: (i) The market is itself a public good, which is very costly to create, and (ii) market-creation requires correct developmental strategies and industrial policies. On the contrary, the economies stuck in the low-income trap or middle-income trap did not follow the above-identified sequential stages of industrial upgrading. For example, many Eastern European and Latin American countries followed leaf-frog development strategies by over-investing too early in heavy industries without fully developing their labor-intensive light industries. Although market forces have stronger incentives to develop light industries than heavy industries, such forces are unable to provide the necessary infrastructure and social capital to render light industries internationally competitive without government help. Also, there is a clear lack of proto-industrialization in the rural areas for many African economies trapped in poverty. This happens not because the government did not allow market competition to operate, but rather because the emergence of rural industries requires the state to provide necessary infrastructure and social capital so that farmers can organize themselves into firms and send their goods to the international markets. Therefore, a government-led and market-size guided sequential industrial upgrading is the key to avoiding the low-income and middle-income traps.

The fundamental theories behind our empirical findings are (i) the Smithian principle that the division of labor is limited by the extent of the market and (ii) the New Stage Theory that the market is itself a public good (and the most fundamental one among all) with three pillars: political stability, social trust, and infrastructure, all of which are extremely costly to provide and thus a "free market" is never free and can only be created step-by-step by a strong and capable mercantilist state guided by correct industrial policies. In this regard, knowledge is power. Our analysis suggests an optimistic prediction that China should be capable of escaping the middle-income trap that has haunted Latin American countries for decades. The "growing pains" facing China's development today, such as an aging population, environmental issues, and a rising debt-to-GDP ratio, would not stop China from becoming a high-income nation by the middle of the $21^{\text {st }}$ century if 15 financial crisis in the 19-century did not stop the United States from becoming a superpower.

\section{Tables}

Table 1. Distribution of Employed Persons by Locality in Taiwan (\%)

\begin{tabular}{|c|c|c|c|c|c|}
\hline & & \multicolumn{3}{|c|}{1966} \\
\hline & Urban & Rural & Urban & \multicolumn{2}{c|}{ Rural } \\
\hline Mining & 59.1 & 40.9 & 55 & 45 \\
\hline Manufacturing & 62.8 & 37.2 & 58.7 & 41.3 \\
\hline Construction & 65.1 & 34.9 & 63.7 & 36.3 \\
\hline Utilities & 68.2 & 31.8 & 66.8 & 33.2 \\
\hline Commerce & 61.1 & 38.9 & 59.4 & 40.6 \\
\hline Transportation and Communication Services & 69.2 & 30.8 & 67.1 & 32.9 \\
\hline
\end{tabular}

Data source: Ho (1979) [20]

Table 2. Structure of Value Added by Manufacturing Sector in South Korea (\%)

\begin{tabular}{|c|c|c|c|c|c|c|c|}
\hline & 1953 & 1960 & 1973 & 1980 & 1990 & 2000 & 2014 \\
\hline Light industry & 87.4 & 83.5 & 72.4 & 60.0 & 52.1 & 50.2 & 44.6 \\
\hline \multicolumn{8}{|l|}{ Traditional light industry } \\
\hline Food, beverage and tobacco & 39.1 & 31.7 & 14.6 & 10.7 & 7.2 & 6.1 & 4.5 \\
\hline Textile, garment, footwear and leather products & 33.3 & 35.9 & 32.4 & 23.2 & 13.4 & 7.9 & 5.1 \\
\hline Wood, furniture, paper and printing & 11.6 & 11.0 & 8.8 & 4.8 & 5.0 & 4.2 & 2.8 \\
\hline Non-metallic mineral products & 1.5 & 2.4 & 5.1 & 6.4 & 6.5 & 4.0 & 2.7 \\
\hline \multicolumn{8}{|l|}{ High-skill light industry } \\
\hline Electrical equipment \& precision instruments & 0.6 & 0.8 & 8.4 & 12.3 & 17.4 & 26.3 & 28.0 \\
\hline Heavy industry & 12.6 & 16.5 & 27.6 & 40.0 & 47.9 & 49.8 & 55.4 \\
\hline Petroleum and chemical products & 5.4 & 7.1 & 13.1 & 19.9 & 14.3 & 15.3 & 15.6 \\
\hline Metals, machinery and transport equipment & 7.2 & 9.4 & 14.5 & 20.2 & 33.6 & 34.5 & 39.7 \\
\hline
\end{tabular}

Data source: Bela Balassa(1971) [5], and Statistics Korea 
Table 3. Structure of Employment by Manufacturing Sector in South Korea (\%)

\begin{tabular}{|c|c|c|c|c|c|c|}
\hline Light industry & 1961 & 1970 & 1979 & 1990 & 2000 & 2006 \\
\hline Traditional light industry & 78.9 & 74.3 & 67.2 & 59.2 & 52.7 & 49.2 \\
\hline Food, beverage, and tobacco & & & & & & \\
\hline Textile, garments, footwear and leather products & 15.7 & 13.6 & 8.8 & 7.3 & 6.9 & 6.8 \\
\hline Wood, furniture, paper and printing & 35.4 & 31.1 & 30.4 & 22.7 & 16.4 & 9.4 \\
\hline Non-metallic minerals products & 13.4 & 10.9 & 8.0 & 7.5 & 7.8 & 7.8 \\
\hline High-skill light industry & 6.0 & 5.9 & 4.8 & 4.4 & 3.3 & 3.0 \\
\hline Electrical equipment and precision instruments & & & & & & \\
\hline Heavy Industry & 6.0 & 7.2 & 11.8 & 17.3 & 18.3 & 22.1 \\
\hline Metals, machinery and transport equipment & 21.1 & 25.7 & 32.8 & 40.8 & 47.3 & 50.8 \\
\hline
\end{tabular}

Data sources: Gary Fields (1985) [14] and CEPII Dataset

Table 4. Structure of Value Added by Manufacturing Sector in Taiwan (\%)

\begin{tabular}{|c|c|c|c|c|c|}
\hline Light industry & 1953 & 1960 & 1980 & 1990 & 1996 \\
\hline Traditional light industry & 78.6 & 73.4 & 57.4 & 52.6 & 49.2 \\
\hline Food, beverage, and tobacco & & & & & \\
\hline Wextile, garments, footwear and leather products & 33.1 & 31.7 & 13.1 & 10.7 & 9.0 \\
\hline Wood, furniture, paper and printing & 23.9 & 16.4 & 17.4 & 12.6 & 9.1 \\
\hline Non-metallic minerals products & 13.3 & 13.7 & 8.0 & 7.0 & 4.7 \\
\hline High-skill light industry & 4.1 & 8.0 & 4.9 & 4.6 & 3.9 \\
\hline Hlectrical equipment and precision instruments & & & & & \\
\hline Heavy Industry & 21.1 & 2.1 & 14.1 & 17.8 & 22.5 \\
\hline Metals, machinery and transport equipment & 6.0 & 13.3 & 20.3 & 25.8 & 27.3 \\
\hline
\end{tabular}

Data source: Bela Balassa(1971)[5], and CEPII Dataset

Table 5. Structure of Employment by Manufacturing Sector in Taiwan (\%)

\begin{tabular}{|c|c|c|c|c|c|}
\hline & 1966 & 1975 & 1981 & 1990 & 2000 \\
\hline Light industry & 72.3 & 67.5 & 66.6 & 56.9 & 54.2 \\
\hline Traditional light industry & & & & & \\
\hline Food, beverage, and tobacco & 12.7 & 10.1 & 6.7 & 5.5 & 4.7 \\
\hline Textile, garments, footwear and leather products & 21.5 & 25.2 & 21.9 & 16.7 & 11.9 \\
\hline Wood, furniture, paper and printing & 11.6 & 9.9 & 11.5 & 8.9 & 7.6 \\
\hline Non-metallic minerals products & 8.8 & 4.9 & 4.3 & 4.3 & 3.6 \\
\hline High-skill light industry & & & & & \\
\hline Electrical equipment and precision instruments & 11.7 & 13.1 & 16.2 & 21.5 & 26.4 \\
\hline Heavy Industry & 27.7 & 32.5 & 33.4 & 43.1 & 45.8 \\
\hline Petroleum and chemical products & 13.1 & 16.2 & 13.2 & 17.4 & 16.1 \\
\hline Metals, machinery and transport equipment & 14.6 & 16.3 & 20.2 & 25.7 & 29.7 \\
\hline
\end{tabular}

Data sources: Gary Fields (1985) [14] and CEPII Dataset

Table 6. Growth of Electronic Industry in Singapore: 1960-1999

\begin{tabular}{|c|c|c|c|c|}
\hline \multirow{2}{*}{ Annual Growth Rate } & \multicolumn{2}{|c|}{ the First Stage } & the Second Stage & the Third Stage \\
\cline { 2 - 5 } & $1960-1970$ & $1970-1980$ & $1980-1990$ & $1990-1999$ \\
\hline Gross Output & 28.7 & 38 & 18 & 10.5 \\
\hline Value Added & 28.8 & 32.6 & 5.5 & 11.2 \\
\hline Labor & 24.6 & 20.3 & -1.6 \\
\hline
\end{tabular}

Data source: Wong and $\mathrm{Ng}(2001)$ [17], Tab.13.1 
Table 7. Product Structure of Electronic Industry in Singapore (\%)

\begin{tabular}{|c|c|c|c|c|c|}
\hline & 1970 & 1975 & 1980 & 1990 & 1998 \\
\hline Consumer electronics & 100 & 30.6 & 38.8 & 17.7 & 3.7 \\
\hline Electronics components & 0 & 69.4 & 54.4 & 35.2 & 27.7 \\
\hline Computers \& peripherals & 0 & 0 & 5.4 & 42.3 & 54.7 \\
\hline Telecom \& others & 0 & 0 & 1.2 & 4.8 & 13.9 \\
\hline
\end{tabular}

Notes: Data is from Wong and $\mathrm{Ng}$ (2001)[44], Tab.13.3. Consumer electronics include TV sets, and other audio and video equipment. Electronic components include semiconductor devices, capacitors and resistors, connectors, and PCBs (mainly assembly before 1990). Computers and peripherals include computers and data processing equipment, disk drivers, printer and other office equipment. Telecom and others include communication equipment, electronic security system and other electronics.

\section{REFERENCES}

[1] Acemoglu D, Johnson S, Robinson J A. The Colonial Origins of Comparative Development: An Empirical Investigation[J]. American Economic Review, 2001, 91(5): 1369-1401.

[2] Aiyar M S, Duval M R A, Puy M D, et al. Growth slowdowns and the middle-income trap[M]. International Monetary Fund, 2013.

[3] Arias M A, Wen Y. Trapped: Few Developing Countries Can Climb the Economic Ladder or Stay There[J]. The Regional Economist, Oct 2015, 2015.

[4] Brandt L, Van Biesebroeck J, Zhang Y. Creative accounting or creative destruction? Firm-level productivity growth in Chinese manufacturing $[\mathrm{J}]$. Journal of Development Economics, 2012, 97(2): 339-351.

[5] Balassa B. Industrial policies in Taiwan and Korea[J]. Weltwirtschaftliches Archiv, 1971, 106(1): 55-77.

[6] Baer W, da Fonseca M A R, Guilhoto J J M. Structural changes in Brazil's industrial economy, 1960-1980[J]. World Development, 1987, 15(2): 275-286.

[7] Cai H, Liu Q. Competition and corporate tax avoidance: Evidence from Chinese industrial firms[J]. The Economic Journal, 2009, 119(537): 764-795.

[8] Chandra V, Lin J Y, Wang Y, 2013. Leading dragon phenomenon: New opportunities for catch-up in low-income countries[J]. Asian Development Review.

[9] Chen B L, Chen T J, Chu Y P. The Role of Textiles and Man-made Fibre in the Process of Industrialization: The Case of Taiwan[J]. Wong and Ng (eds.), 2001: 283-321.

[10] Desai P, Martin R. Efficiency loss from resource misallocation in Soviet industry[J]. The Quarterly Journal of Economics, 1983: 441-456.

[11] Easterly W. Reliving the 1950s: the big push, poverty traps, and takeoffs in economic development[J]. Journal of Economic Growth, 2006, 11(4): 289-318.

[12] Feenstra R C, Inklaar R, Timmer M P. The next generation of the Penn World Table[J]. The American Economic Review, 2015, 105(10): 3150-3182.

[13] Felipe J, Abdon A, Kumar U. Tracking the middle-income trap: What is it, who is in it, and why? $[\mathrm{J}]$. Levy Economics
Institute, Working Paper, 2012 (715).

[14] Fields G S. Industrialization and Employment in Hong Kong, Korea, Singapore, and Taiwan[J]. 1985.

[15] Gill I., Kharas H. An East Asian Renaissance: Ideas for Economic Growth [J]. Washington D.C.: World Bank, 2007

[16] Gerschenkron A. Economic backwardness in historical perspective: a book of essays[R]. Cambridge, MA: Belknap Press of Harvard University Press, 1962.

[17] Hayami Y. Toward the rural-based development of commerce and industry. Selected experiences from East Asia[M]. World Bank, 1998.

[18] Haggblade, S., Hazell, P. B., \& Reardon, T. (Eds.). Transforming the rural nonfarm economy: Opportunities and threats in the developing world[M]. Intl Food Policy Res Inst, 2007

[19] Hsieh C T. Grasp the Large, Let Go of the Small: The Transformation of the State Sector in China[J]. Brookings Papers on Economic Activity, 2015, 295.

[20] Ho S P S. Decentralized industrialization and rural development: evidence from Taiwan[J]. Economic Development and Cultural Change, 1979, 77-96.

[21] Holz C A. New capital estimates for China[J]. China economic review, 2006, 17(2): 142-185.

[22] Im F G, Rosenblatt D. Middle-income traps: a conceptual and empirical survey[J]. Journal of International Commerce, Economics and Policy, 2015, 6(03): 1550013.

[23] Kuznets S S. Economic growth of nations[J]. 1971.

[24] Li, S., Luo, C., Wei, Z., and Yue, X. (2008), “Appendix: The 1995 and 2002 Household Surveys: Sampling Methods and Data Description," in B. Gustafsson, S. Li, and T. Sicular, eds., Inequality and Public Policy in China, 337-353, New York: Cambridge University Press.

[25] Lin J Y. 2011. New structural economics: a framework for rethinking development $[\mathrm{J}]$. The World Bank Research Observer, 2011: $1 \mathrm{kr} 007$.

[26] Lin, J Y, 2013. The Quest for Prosperity: How Developing Economies can Take Off. Princeton University Press.

[27] Lin J Y, Fu C. Report on Structural Transformation in Countries across the World[R]. the Center for New Structural Economics, Peking University, 2016.

[28] Loening J, Mikael Imru L. Ethiopia: diversifying the rural economy. An assessment of the investment climate for 
small and informal enterprises[J]. 2009.

[29] Loening J, Lane W L. Tanzania: Pilot Rural Investment Climate Assessment. Stimulating Nonfarm Microenterprise Growth[J]. 2007.

[30] Luo J, Wen Y. Institutions Do Not Rule: Reassessing the Driving Forces of Economic Development[J]. FRB St Louis Paper No. FEDLWP2015-001, 2015.

[31] Mendels, F.F., 1972. Proto-industrialization: the first phase of the industrialization process. The journal of economic history, 32(1), pp.241-261.

[32] North D. Institutions[J]. Journal of Economic perspectives, 1991, 5(1): 640-655.

[33] O'Connor D C. Technology and industrial development in the Asian NIEs: past performance and future prospects[J]. The Emerging technological trajectory of the Pacific Rim, 1995: 55.

[34] Parente S L, Prescott E C. Barriers to technology adoption and development[J]. Journal of political Economy, 1994: 298-321.

[35] Parente S L, Prescott E C. Barriers to riches[M]. MIT press, 2000.

[36] Pomeranz K. The great divergence: China, Europe, and the making of the modern world economy[M]. Princeton University Press, 2009.
[37] Ranis G. Challenges and opportunities posed by Asia's superexporters: Implications for manufactured exports from Latin America[M]//Export diversification and the new protectionism: The experience of Latin America. Bureau of Economic and Business Research, University of Illinois at Urbana-Champaign, 1981: 204-230.

[38] Rodrik D. Premature deindustrialization[J]. Journal of Economic Growth, 2016, 21(1): 1-33.

[39] Sachs J D. Institutions don't rule: direct effects of geography on per capita income[R]. National Bureau of Economic Research, 2003.

[40] Sachs J, McArthur J W, Schmidt-Traub G, et al. Ending Africa's poverty trap $[\mathrm{J}]$. Brookings papers on economic activity, 2004, 2004(1): 117-240.

[41] Smith T C. Landlords and rural capitalists in the modernization of Japan[J]. The Journal of Economic History, 1956, 16(02): 165-181.

[42] Smith T C. Native sources of Japanese industrialization, 1750-1920[M]. Univ of California Press, 1988.

[43] Wen, Y. The Making of an Economic Superpower-Unlocking China's Secret of Rapid Industrialization.[M]. World Scientific Co. Publisher, 2016.

[44] Wong, P K, and Ng C Y, eds. Industrial policy, innovation and economic growth: The experience of Japan and the Asian NIEs.[M]. NUS Press, 2001.

\footnotetext{
i We appreciate helpful comments from Justin Yifu Lin, Yong Wang, Caihui Fu, Jack W. Hou, and other participants at the 13th WEA International Conference and the 2017 China Meeting of Econometric Society.
} 